University of Nebraska - Lincoln

DigitalCommons@University of Nebraska - Lincoln

Publications from USDA-ARS / UNL Faculty

U.S. Department of Agriculture: Agricultural

Research Service, Lincoln, Nebraska

2017

\title{
Human Land-Use and Soil Change
}

Skye A. Wills

USDA-NRCS, skye.wills@lin.usda.gov

Candiss O. Williams

USDA-NRCS, Candiss.williams@lin.usda.gov

Michael C. Duniway

US Geological Survey, mduniway@usgs.gov

Jessica Veenstra

Flagler College, JVeenstra@flagler.edu

Cathy Seybold

USDA-NRCS, cathy.seybold@lin.usda.gov

See next page for additional authors

Follow this and additional works at: https://digitalcommons.unl.edu/usdaarsfacpub

Wills, Skye A.; Williams, Candiss O.; Duniway, Michael C.; Veenstra, Jessica; Seybold, Cathy; and Presley, DeAnn, "Human Land-Use and Soil Change" (2017). Publications from USDA-ARS / UNL Faculty. 1862. https://digitalcommons.unl.edu/usdaarsfacpub/1862

This Article is brought to you for free and open access by the U.S. Department of Agriculture: Agricultural Research Service, Lincoln, Nebraska at DigitalCommons@University of Nebraska - Lincoln. It has been accepted for inclusion in Publications from USDA-ARS / UNL Faculty by an authorized administrator of DigitalCommons@University of Nebraska - Lincoln. 


\section{Authors}

Skye A. Wills, Candiss O. Williams, Michael C. Duniway, Jessica Veenstra, Cathy Seybold, and DeAnn Presley 


\author{
Skye A. Wills, Candiss O. Williams, Michael C. Duniway, \\ Jessica Veenstra, Cathy Seybold, and DeAnn Presley
}

\subsection{Introduction}

Soil change is the central, if under-recognized, component of land and ecosystem changes (Yaalon 2007). Soils change naturally over a long timescale (decades to millennia) in response to soil-forming factors (biota, climate, parent material, time, and topography). However, human land-use pressures are currently the driving force in maintaining, aggrading, and degrading soil properties across nearly all ecosystems. Traditionally, in order to simplify and standardize the relationships between soils and soil-forming factors, pedology and soil survey have often focused on "natural" or "virgin" soil (e.g., Hilgard 1860; Jenny 1980), but many argue that humans should be thought of as a part of soil genesis and formation (Amundson and Jenny 1991; Yaalon and Yaron 1966; Bidwell and Hole 1965).

Landscapes and soils have been altered by wide-scale conversion to agriculture, use of vegetative products, and development for direct human use. Land-use impacts can be gradual or abrupt, subtle, or catastrophic (Table 18.1). The interactions between environmental changes and geomorphic and biotic feedback loops vary across temporal and spatial scales depending on the setting (Monger and

S.A. Wills $(\square) \cdot$ C.O. Williams · C. Seybold

USDA-NRCS, Lincoln, NE, USA

e-mail: Skye.wills@lin.usda.gov

C.O. Williams

e-mail: Candiss.williams@lin.usda.gov

C. Seybold

e-mail: Cathy.seybold@lin.usda.gov

M.C. Duniway

US Geological Survey, Moab, UT, USA

e-mail: mduniway@usgs.gov

J. Veenstra

Flagler College, St. Augustine, FL, USA

e-mail: JVeenstra@flagler.edu

D. Presley

Kansas State University, Manhattan, KS, USA

e-mail: deann@ksu.edu
Bestelmeyer 2006). The effects of land use can linger for decades to centuries and beyond (Hall et al. 2013; Jangid et al. 2011; Sandor et al. 1986). While each land resource region has some specific soil-land use interactions, this chapter will focus on general uses and topical areas: croplands, wetlands, grazing lands (both pasture and rangelands), and forest lands with smaller sections devoted to special issues including acid sulfate soils, strip-mined lands, and cold soils.

\subsubsection{Concepts of Soil Change}

Soil change refers to the variation of soil properties in one location over time. The concept of "soil change" has been proposed as a framework for understanding and documenting the impact of human use and management on soil properties and function (Arnold et al. 1990; Palm et al. 2007; Richter and Markewitz 2001; Robinson et al. 2012; Tugel et al. 2005, 2008). Management of soil resources, directly or indirectly, can alter soil properties and soil functions both negatively and positively. While all management (even its absence) impacts soil conditions, some impacts are intensive and site specific while others are extensive (Grigal 2000). The direction of change depends on the nature of the management, the goals of the management action, and the framework for measuring outcomes. While management actions to increase soil fertility might lead to improved soil function (for instance, crop productivity) at a local scale, a broader watershed scale might assess decreased soil function (for instance, nutrient filtering and buffering that influence eutrophication).

Soil change in this chapter refers to disturbances caused directly or indirectly by human land use and management. Palm et al. (2007) refers to soil degradation as a change that causes a reduction in ecosystem function (as in Fig. 18.1). 
Table 18.1 Types of soil change ranging from landscape alteration to cyclical fluctuations

\begin{tabular}{|c|c|c|c|c|}
\hline $\begin{array}{l}\text { Landscape } \\
\text { alteration }\end{array}$ & $\begin{array}{l}\text { Taxonomic } \\
\text { classification }\end{array}$ & Phase distinctions & Surface properties & Cyclical fluctuations \\
\hline $\begin{array}{l}\text { Drastically altered } \\
\text { arrangement of } \\
\text { materials } \\
\text { - Removal or } \\
\text { transport of } \\
\text { material } \\
\text { - Gully erosion } \\
\text { - Landslides }\end{array}$ & $\begin{array}{l}\text { Alteration or } \\
\text { mixing of horizons } \\
\text { - Extension } \\
\text { erosion or } \\
\text { deposition } \\
\text { changes soil } \\
\text { interacting with } \\
\text { the environment } \\
\text { - Large changes in } \\
\text { nutrient or base } \\
\text { status due to } \\
\text { long-term } \\
\text { management }\end{array}$ & $\begin{array}{l}\text { Distinction soil features } \\
\text { remain intact with } \\
\text { relatively unaltered } \\
\text { subsurface features } \\
\text { (control section) } \\
\text { - Low-to-moderate } \\
\text { erosion } \\
\text { - Drainage }\end{array}$ & $\begin{array}{l}\text { Dynamic soil properties that } \\
\text { change with land use or } \\
\text { management } \\
\text { - Nutrients } \\
\text { - Aggregates } \\
\text { - Organic matter }\end{array}$ & $\begin{array}{l}\text { Regular, periodic, or cyclical } \\
\text { fluctuations } \\
\text { - Soil moisture } \\
\text { - Temperature } \\
\text { - Water table }\end{array}$ \\
\hline \multicolumn{5}{|c|}{ Change in soil and ecosystem functions } \\
\hline $\begin{array}{l}\text { High, catastrophic } \\
\text { change to } \\
\text { functions relating } \\
\text { to soil stability and } \\
\text { productivity }\end{array}$ & $\begin{array}{l}\text { Variable, depends } \\
\text { on the taxonomic } \\
\text { system used and } \\
\text { classes crossed }\end{array}$ & $\begin{array}{l}\text { Moderate, soil capacity, } \\
\text { or potential may remain } \\
\text { intact, but sensitive } \\
\text { functions may be } \\
\text { disrupted }\end{array}$ & $\begin{array}{l}\text { Moderate to low, depends on } \\
\text { type and magnitude of soil } \\
\text { property change as well as } \\
\text { the constraints upon the } \\
\text { ecosystem }\end{array}$ & $\begin{array}{l}\text { Variable. Typical fluctuations } \\
\text { occur as part of highly functioning } \\
\text { soil systems. However, alteration } \\
\text { to the timing and amplitude of } \\
\text { fluctuations can greatly modify } \\
\text { soil functions }\end{array}$ \\
\hline
\end{tabular}

Adapted from Tugel et al. (2008)

Table 18.2 Summary of effects of tillage and residue management on soil physical properties in small grains cropping systems at the end of 20 years in interior Alaska

\begin{tabular}{|c|c|}
\hline Tillage/residue & Effects on soil properties \\
\hline Intensive $^{\mathrm{a}}$ & $\begin{array}{l}\text { Had the most detrimental effects on soil physical properties and was found to be the least effective in reducing soil } \\
\text { loss during high wind events }\end{array}$ \\
\hline Autumn chisel & $\begin{array}{l}\text { Promoted greater roughness, aggregation, and residue cover compared with intensive tillage; random roughness was } \\
\text { greater for autumn chisel compared to all other tillage treatments. Infiltration was greater compared to all other tillage } \\
\text { treatments }\end{array}$ \\
\hline Spring disk & Promoted greater roughness, aggregation, and residue cover compared with intensive tillage \\
\hline No tillage & $\begin{array}{l}\text { Had larger aggregates, greater soil strength (penetration resistance and shear stress at the surface), wetter soil, and } \\
\text { greater residue cover compared to all other tillage treatments; resulted in an organic layer on the soil surface (after } \\
20 \text { years) which suppressed infiltration; had higher saturated hydraulic conductivity and retained more water against } \\
\text { gravitational and matric forces versus intensive tillage }\end{array}$ \\
\hline $\begin{array}{l}\text { Crop residue } \\
\text { management }^{b}\end{array}$ & $\begin{array}{l}\text { Influenced residue biomass and cover (the response was dependent on tillage treatment). No tillage resulted in } 100 \% \\
\text { residue cover, while residue cover ranged from } 2 \text { to } 4 \% \text { on all other tillage treatments. Crop residue management did } \\
\text { not influence soil properties }\end{array}$ \\
\hline
\end{tabular}

Summarized from Sharratt et al. (2006a, b)

${ }^{\mathrm{a}}$ Intensive $=$ autumn chisel and spring disk

${ }^{\mathrm{b}} \mathrm{Crop}$ residue management treatments were residue removed and residue retained after harvest

The resistance and resilience of a soil refer to the capacity of a particular soil to respond to a disturbance (Seybold et al. 1999). A soil is resistant if it does not change functionality after a disturbance or management impact occurs. Lal (1993) uses the term soil stability for the same concept. A soil is resilient if it recovers its initial qualities after a disturbance (Seybold et al. 1999). Resilience can be applied to landscapes, soil profiles, or individual properties and are important for predicting and assessing soil change.

\subsubsection{Measuring Soil Change}

An assessment of soil change depends upon the metrics of soil and ecosystem function evaluated. Richter and Markewitz (2001) illustrated an approach that used an in-depth evaluation of an experimental forest to represent regional soil change that has occurred over centuries. Richter et al. (2011) expanded on the limits of a soil management approach and emphasized the need to understand soil 
(a)

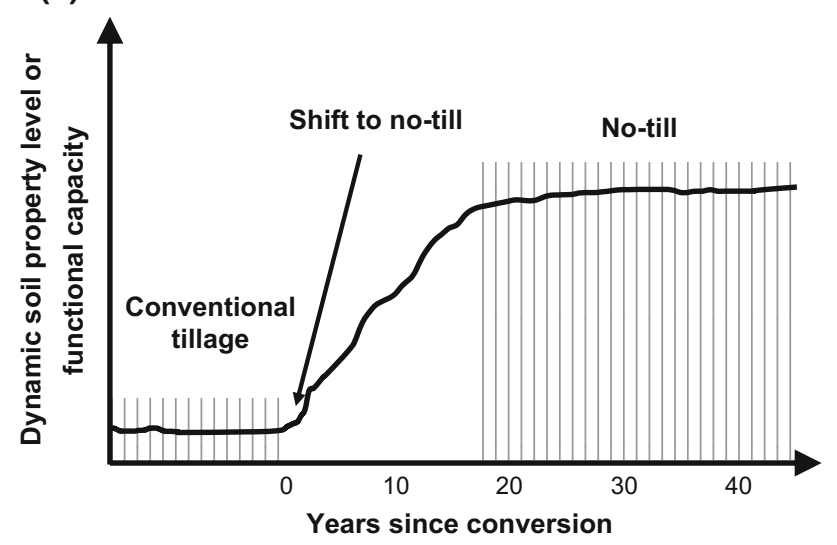

(b)
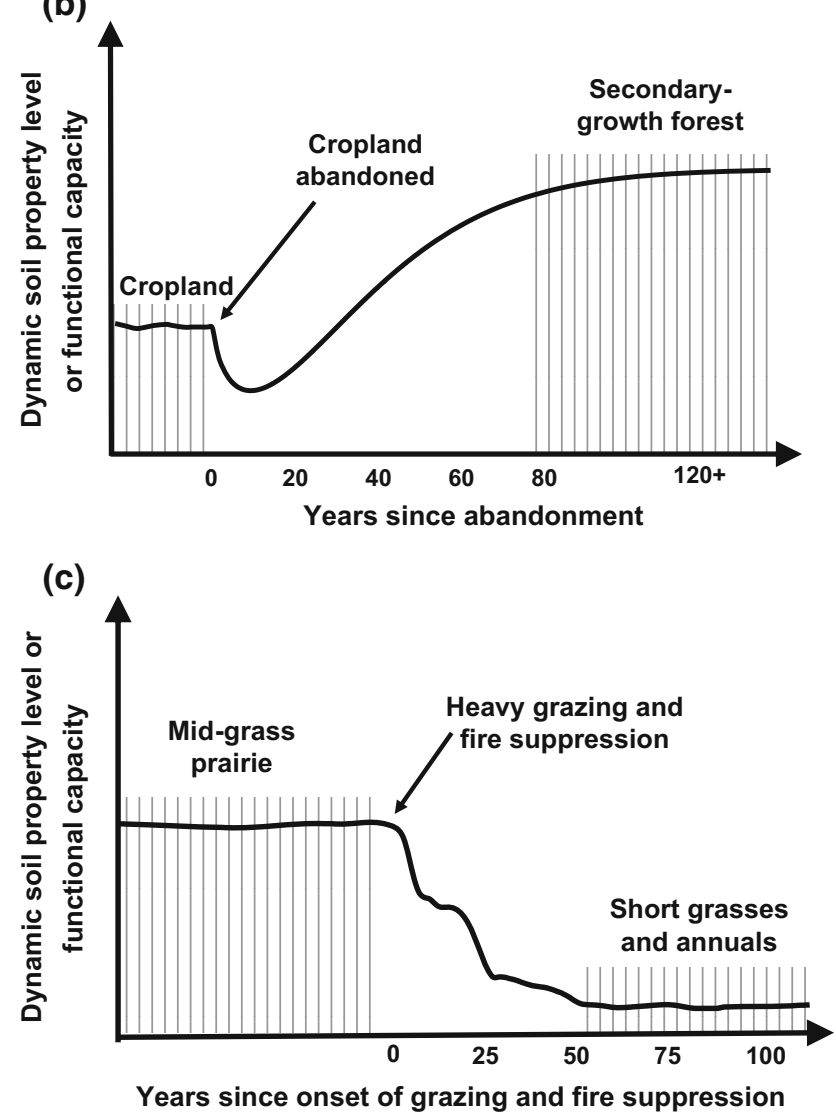

Fig. 18.1 Three examples of expected soil organic $\mathrm{C}$ change after management change. The arrows point to a disturbance that may have positive or negative impacts: a Conversion from conventional tillage to no till. West and Post (2002) found that maximum SOC accumulation (average increase of $0.6 \mathrm{~kg} \mathrm{~m}^{-2}$ ) occurred within $15-20$ years after conversion to no till. b Secondary forest succession after field abandonment. Curve from 1 to 80 years based on soil $\mathrm{N}$ level in a Minnesota chronosequence (Zak et al. 1990). SOC followed a similar trajectory and increased from 1.25 to $2.10 \mathrm{~kg} \mathrm{~m}^{-2}$ during the same period. c Change from reference state after grazing and absence of fire in a grassland system. Adapted from Tugel et al. (2005) and based on data from Archer et al. (2001). Archer et al. (2001) simulated a SOC reduction of $16 \%$ in a sandy loam and $29 \%$ in a clay loam over a period of about 50 years after the onset of heavy grazing and fire suppression genesis through the concepts of the Anthropocene (the "age of humans"). Ecology and economic disciplines have attempted to document soil change in terms of the natural environment and ecosystem functions and to apply monetary metrics to ecosystem services (Costanza et al. 1997; Goudie 2013).

The spatial and temporal frameworks implemented in soil change studies depend upon the nature of the agents of change, system attributes, and types of soil change of most concern (Table 18.1; Fig. 18.1). However, since there are often no good records of historical soil properties, techniques such as "space-for-time substitution" have been used to compare soils that differ only in management or other disturbance (Pickett 1989). This technique requires that other soil-forming factors (parent material, climate, organisms, relief, and time) be held constant to the extent possible and that the conceptual model of soil change be explicitly considered and documented (Tugel et al. 2008). Soil survey and environmental covariates that represent soil-forming factors can be used to choose comparable locations. When possible, monitoring the same location over time improves understanding of the processes and mechanisms of soil change. Variability in soil with spatial extent, management applications, and weather phenomena means that measuring and interpreting soil change are not simple or straightforward. While humans have been active managers of soil and ecosystem resources for millennia (Nir 1983), the degree and amount of change have accelerated in recent centuries (Richter et al. 2011). In the United States, the time of European settlement is often used as a reference to assess soil change across ecosystems and regions (i.e., Richter and Markewitz 2001). The scale and type of soil change being investigated may require alternate reference states for relevant comparisons (Fig. 18.1).

When measurements of soil change are focused on management-relevant timelines (months to decades) and spatial scales (e.g., field or paddock), the concept of soil quality is useful. Soil quality and soil health are terms used to indicate the ability of soils to perform functions, such as support and stability, productivity, and cycling, filtering, and buffering (Doran and Parkin 1994; Karlen et al. 1997; Singer and Ewing 2000). Assessments of soil quality and health are often used to assess soil change and intermediate scales of human management (i.e., Tugel et al. 2005).

\subsubsection{Monitoring and Modeling Soil Change}

Soil as a component of agricultural and environmental ecosystems is well studied. However, there is growing emphasis on long-term studies that focus on change in soil properties (i.e., university- and government-led agricultural research). While soil degradation may occur quickly as a 
result of practices on the land, studies have shown that agricultural management improvements of soil properties are likely to be observed and quantified in long-term studies (Lal 1993; McVay et al. 2006, Wood and Edwards 1992). The importance of quantifying land management practices on soil properties is well identified. However, ongoing soil sampling and monitoring to quantify changes in soil properties as a result of management and/or environmental changes is relatively new and is greatly needed to develop guidelines and criteria for decision-making (Lal 1993; Lawrence et al. 2013). Long-term studies also allow for a wide range of environmental conditions in addition to land management. These conditions allow for the inclusion of episodic events (i.e., drought) or slower events such as changes in land use and climate. In addition, long-term studies provide necessary data for the calibration and validation of crop and environmental simulation models used to forecast changes (Hobbie et al. 2003; Robertson et al. 2008; Williams et al. 2008).

Guidelines and criteria for understanding how management practices influence changes in soil properties can only be developed if long-term experimental data are available (Lal 1993). Since the inclusion of repetitive soil sampling in long-term studies is relatively new and questions relating to long-term impacts of management on soil properties may be difficult to ascertain from data collected from networks, alternative approaches such as space-for-time (Pickett 1989; Tugel et al. 2005; Blois et al. 2013) and computer modeling (Kelly et al. 1997; Smith et al. 1997; Izaurralde et al. 2006) have been used.

Space-for-time studies encompass analyses in which current spatial phenomena are used to understand and model processes that are unobservable (Blois et al. 2013) such as the impact of management change on soil properties that were implemented in the past and their likely impact long term. Space-for-time measurements have limitations in soil management research due to changes in climate and management over time. Computer models are more commonly used in soil management research to estimate the effects of management on changes in soil properties and are increasingly important tools for short- and long-term assessments (Williams and Sharpley 1989; Lowrance et al. 2000; Izaurralde et al. 2006; Williams et al. 2008, 2013) especially when measured data are limited and forecasting is necessary. The disadvantage of using computer models, however, is the inherent uncertainty. Soils are part of a complex system, and models may not be able to simulate such complexities as simultaneous interaction between physical, chemical, biological, climatic conditions, and the calibration process.

\subsection{Soil Change in Croplands}

Soils in the USA have been altered to provide food and fiber for millennia. While Native Americans altered landscapes for hunting and farming, European settlement and clearing for agriculture resulted in a marked acceleration of soil change (Richter and Markewitz 2001). Eastern forests were first cleared for production agriculture in the early 1800s (Ramankutty et al. 2010), and the impact on soil properties can only be postulated by observing relatively undisturbed areas or inferring from modern-day disturbance studies (as in space-for-time). The immediate impacts of deforestation likely include increased soil temperature, altered moisture regime, and modified nutrient cycles (Vitousek et al. 1983).

As agricultural development progressed westward, grasslands were plowed and wetlands drained for cropland uses (Ramankutty and Foley 1999). Even where native vegetation regenerated, the effect of cropping has lingered in soil properties from decades (Bellemare et al. 2002; Guzman and Al-Kaisi 2010) to centuries (McLauchlan 2006; Sandor et al. 1986). While using soils for cropland can cause multiple disturbances to soil functions through the introduction of monocultures, the addition of inorganic fertilizers and pesticides, and irrigation, the most direct impact comes from physical disruption.

The Morrow plots at the University of Illinois were established in 1876 to answer questions about agricultural management (Odell et al. 1982). Initial results indicated that growing corn depleted soil organic matter and associated soil fertility. Introducing inorganic fertilizer and crop rotations improved yields but did not return soil conditions to their original status. Other long-term observation plots such as the Sanborn Field in Missouri (Brown 1993), the Magruder plots in Oklahoma (Webb et al. 1980), and long-term studies in Oregon (Rasmussen et al. 1998) and Nebraska (Peterson et al. 2012), all reported decreases in SOC over time with cropping. The world's oldest continuous cotton experiment, called "The Old Rotation" in Auburn, AL, has demonstrated that changes to management systems (tillage and rotation) can increase SOC concentrations (and improve other soil properties and functions) (Hubbs et al. 1998; Mitchell et al. 2008; Prieto et al. 2002).

Tillage changes the physical arrangement of soil particles, which has cascading effects on chemical and biological properties (Bronick and Lal 2005). The disruption of soil structural integrity with tillage leads to the breaking apart of soil aggregates and breakdown of soil organic matter. Cambardella and Elliott (1992) studied Mollisols in Iowa under native prairie or sod and intensively cropped 
conditions. They found that carbon and nitrogen dynamics were linked to particulate organic matter (POM) and soil structural units or aggregates. The soil structure was disturbed due to tillage, therefore leading to a breakdown of larger aggregates and decrease in SOC. Six et al. (1998) found similar results and showed that tillage intensity was related to POM and structural stability and later linked aggregate sizes directly to the SOC they contained (Six et al. 2000).

Tillage also leads to changes in mechanical impedance (Bennie 1990), which can be described in terms of soil bulk density and soil strength (often measured as penetration resistance). These physical properties impact plant growth, water infiltration, and water storage (Dao 1993; Ehlers et al. 1983; Lampurlanés and Cantero-Martínez 2003). Changes in physical properties may increase erosion on summits and sideslopes and deposition in footslopes and depressions (e.g., Daniels et al. 1985; Beach 1994; Konen 1999; Norton 1986), and therefore can alter watershed hydrology (Johnson et al. 1980). In some cases, erosion and deposition can alter the soil profile and therefore, the classification (taxa) and mapping of soil bodies (Indorante et al. 2014; Fenton 2012).

Limiting the impact of agricultural practices on erosion has long been a goal of conservation efforts, and recent conservation efforts are focusing on soil health with emphasis on soil biology (Morgan 2009; Lindbo et al. 2014). There are complex interactions between soil types, management systems, and the impact of tillage on soil ecology (Kladivko 2001). Microbial diversity and activity in the soil have been shown to be a signal of the overall function of soil chemical and physical systems (Torsvik and Øvreås 2002; Wander et al. 1995; Wardle et al. 1999).

New developments in agricultural technology (conservation or reduced and no-tillage cropping systems) have led to improvements in soil properties. For instance, Blanco-Canqui et al. (2009) reported that a no-till cropping system increased SOC and decreased bulk density. Rhoton et al. (2002) observed improvements with low-tillage systems in organic matter and physical structure, which lead to increased infiltration and decreased runoff. Furthermore, developments in crop rotations, cover crops, and reduced chemical disturbance (inputs of inorganic nutrients and pesticides) have led to improvements in soil biological function (Doran 1980; Parkinson and Coleman 1981; Spedding et al. 2004). Although the improvements in soil properties were observed in these studies, recovery of some soil properties may take longer than most management time frames (Fig. 18.2). See Sect. 18.2.3 for a discussion of erosion that cannot be reversed on a human timescale with even the best management.

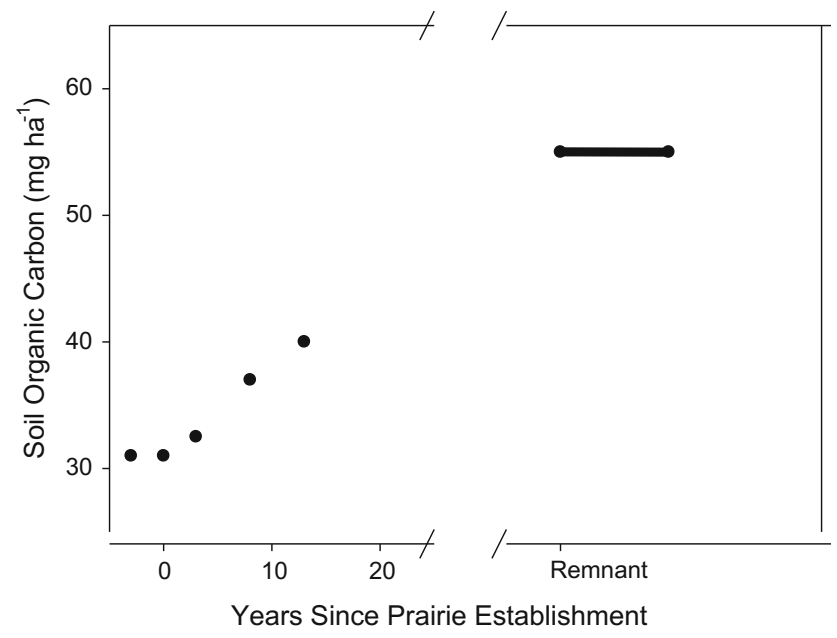

Fig. 18.2 Soil organic $\mathrm{C}$ after tillage and restoration in an Iowa Mollisol. Initial tillage was approximately 150 years ago. Each point represents one site. Adapted from Guzman and Al-Kaisi (2010)

\subsubsection{Impacts of Cropping on Soils of the Great Plains of the USA}

Mollisols are the predominant soils in the Great Plains (Chap. 8), and because of inherent soil fertility, the soils in this region are intensively cropped. Strong gradients in annual precipitation and temperature are present in this region, and lead to a range of management choices by agricultural producers, including crop rotations, cropping intensity, amendments, and tillage operations. Access to irrigation water from either aquifers (such as the Ogallala, High Plains, and Equus Beds) or surface water is also an important factor in crop production in the Great Plains. The Great Plains is an extremely important center of agricultural production. However, it is also a region that has numerous challenges including losses of soil from erosion, low precipitation in the west, intense thunderstorms, and declining aquifer levels for irrigation. Water is the most limiting resource to attaining maximum crop yield potential (Nielsen et al. 2005). During the 1930s, the farming of marginal lands in the Great Plains, combined with a prolonged drought, culminated in dust storms and soil destruction of disastrous proportions (Goudie and Middleton 1992). This period, known as the "Dust Bowl," inflicted great hardships on the people and the land, and has been called the greatest ecological disaster to have occurred in the USA (Cook et al. 2009). The erosion and deposition events of the dust bowl created shallow low-fertility soils in some areas and buried soils in others leading to reduced agricultural productivity (Hansen and Libecap 2003; Hornbeck 2009).

A traditional Great Plains dryland cropping system was wheat/fallow with conventional tillage during the fallow 
period for weed control. During the past $\sim 20$ years, primarily due to developments in chemical weed control, a shift has occurred toward reduced or no tillage, and has allowed for more intensive rotations, thus reducing the amount of fallow. Declines in soil organic matter have been documented with tillage and summer fallow, and changing to no-till or more intensive crop rotation has been found to increase soil organic matter levels, though not to the original levels (Hartman et al. 2011; Mikha et al. 2012; Peterson et al. 1998). For these reasons, and because of agronomic and environmental advantages including increased stored water, decreased wind and water erosion, increased $\mathrm{C}$ storage, and overall increased grain yields, no-till practices have increased (Reicosky and Saxton 2007). Decreasing the fallow period or rotating wheat with other crops has shown to sequester $\mathrm{C}$ at greater rates than either the wheat-fallow or continuous wheat (West and Post 2002; Sainju et al. 2006). McVay et al. (2006) summarized five long-term studies across a precipitation gradient in Kansas and observed that decreased tillage, increased fertilization, and crop rotations that included at least one cereal crop in the rotation increased SOC in the surface $5 \mathrm{~cm}$, while no significant changes were observed at other depths.

Irrigation has been observed to affect the soil organic matter of some Great Plains soils. Bordovsky et al. (1999) found that irrigation led to increases in total $\mathrm{C}$ for semi-arid sandy soils in Texas, while Lueking and Schepers (1985) observed increased total $\mathrm{C}$ for sandy soils in Nebraska. Williams (2001) observed increased SOC with irrigation for drier upland soils, and no increase for wetter lowland soils in a study conducted on fine-textured soils of Konza Prairie in eastern Kansas. Presley et al. (2004) measured no changes in SOC for the upper $0.3 \mathrm{~m}$ of irrigated silt loams and silty clay loams in western Kansas, as compared with dryland soils sampled from the corners of a center-pivot irrigated field. However, it is critical to note that irrigation is not the only management practice that differs; dryland fields receive lower inputs of $\mathrm{N}$ and produce less biomass than the irrigated portion of the field and are also less productive. It seems that the effect of irrigation is dependent upon inherent soil properties that include soil texture, drainage class, and/or slope position, among others.

\subsubsection{Impacts of Cropping in the Southeastern USA}

In the southeastern USA, agriculture created some unique problems due to the predominance of low-fertility Ultisols. In the $1800 \mathrm{~s}$, farmers in the southeastern USA managed these soils by shifting agriculture, clearing forests, and growing cotton and tobacco with little to no fertilizer additions until the land would no longer yield, and then moving their fields (Gray 1933; Trimble 1974).

In addition to depleted soil fertility, shifting to row-crop agriculture practices in this region accelerated erosion rates. Ultisols can be very stable under native forest cover, but once the forest cover is removed, in combination with the high-intensity rainfall that is common to the region, they can be subject to high degrees of soil loss (Trimble 1974). The years 1860-1920 were the period of the most erosive land use in the Southern Piedmont (Fig. 13.1). In 1934, $3100 \mathrm{~km}^{2}$ of the Piedmont was reported to be destroyed by gully erosion with $85 \%$ of the affected area being in South Carolina and Georgia (Trimble 1974). An extreme example of this type of soil loss from the nearby Coastal Plain region is Providence Canyon State Park in southwest Georgia, which is referred to as "Georgia's Little Grand Canyon" (Fig. 18.3). In 1820, the Creek Native Americans ceded the land area that included modern-day Providence Canyon; settlement and row-crop agriculture quickly followed. The removal of forest led to gully erosion and the development of a canyon $50 \mathrm{~m}$ deep and several hundred meters wide in places (Froede and Williams 2004). Paleolimnological studies confirm that the period of most extreme historical erosion in the canyon occurred between 1840 and 1880 (Hyatt and Gilbert 2000).

After the US Civil War (1865), continuous cultivation and fertilization became more common (Sheridan 1979), whereas soil conservation practices became more common after the 1930s (Trimble 1974). Studies from the Calhoun Experimental Forest in South Carolina showed that long-term cultivation and fertilization of the Ultisols in the southeastern USA induced deep and long-lasting changes in soil properties including changes in bulk density, $\mathrm{pH}$, nutrients, and exchangeable cations (Richter and Markewitz 2001). Also in the southeastern USA, Levi et al. (2010) reported similar results and suggested that anthropogenic amendments have actually changed the soil classification from Ultisols to Alfisols.

An example of soil change caused by tillage for agricultural production resulted from the development of the rock plow in 1951 (US Patent $2573977^{1}$ ). The rock plow was designed to break up "solid formations of rock, coral, or slag" and prepare the soil for fruit trees and row-crop production. The rock plow was designed for the shallow, oolitic limestone soils of south Florida. Before the rock plow was developed, growers used dynamite to blast holes in the ground in order to plant fruit trees (Derr 1998). As of 2007, 339,960 ha. in south Florida have been transformed by the rock plow, while only 14,074 ha. of the native soil remain

\footnotetext{
${ }^{1}$ Any use of trade, product, or firm names is for descriptive purposes only and does not imply endorsement by the US Government.
} 
Fig. 18.3 The walls of Providence Canyon, in southeastern Georgia. This massive gully formed when the land was cleared for agriculture in the early 1800 s. A thick Ultisol is exposed at the surface.

(Photograph credit: Aaron Daigh)
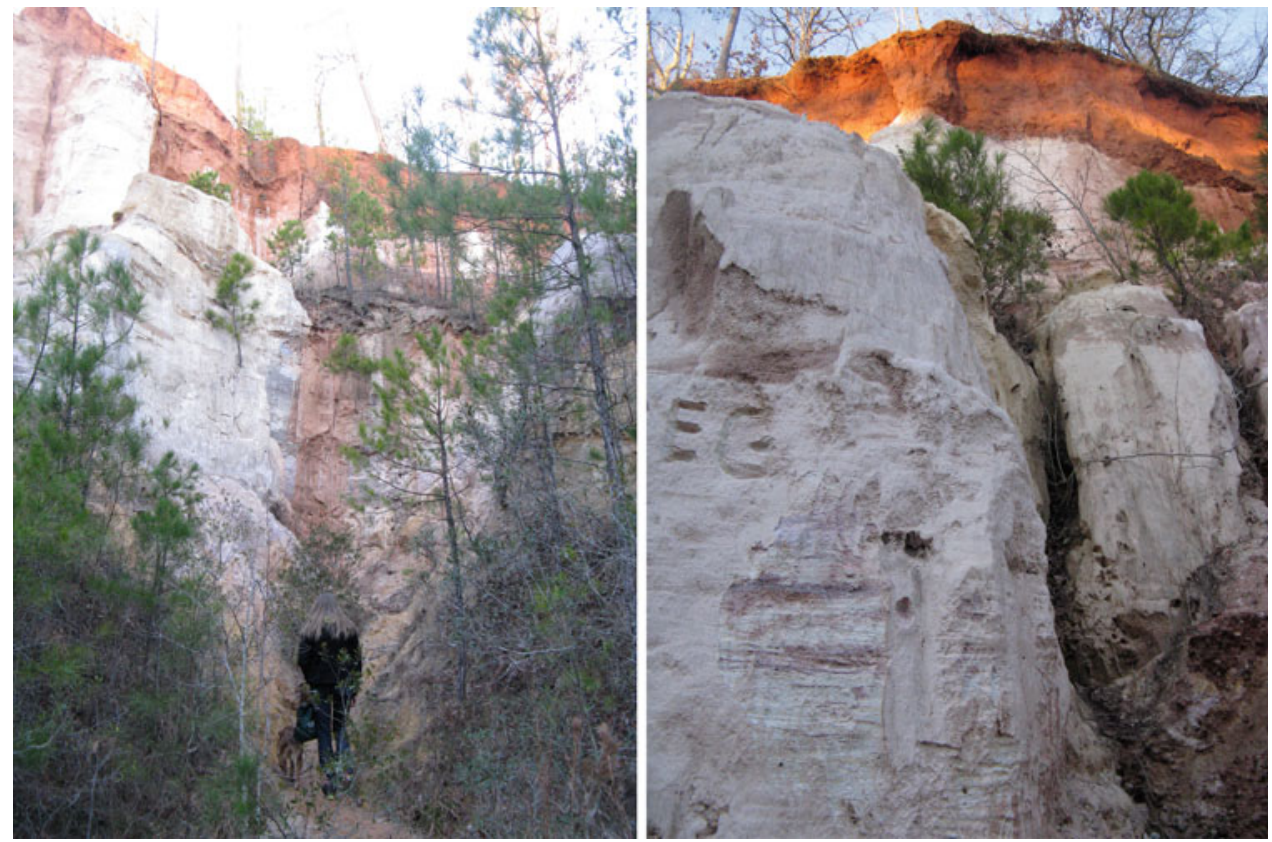

(Soil Survey Staff 2007). Rock plowing results in soils that are a several centimeters thicker than the native soils, and much gravellier (from $12 \%$ in the native soil to $35-70 \%$ in the rock plowed soil). Therefore, despite the fact that management accelerated physical weathering, the resulting soil textures are coarser, rather than finer than the native soils.

\subsubsection{Impact of Cropping on Arid and Irrigated Soils}

Dry soils, referred to as Aridisols in Soil Taxonomy (Soil Survey Staff 1999), pose unique management challenges and respond to cropping systems in unique ways. Dry soils may have taken long periods to develop and have limited inputs for restoring functionality; their resistance to change and resilience may be low (Homburg and Sandor 2011; Seybold et al. 1999). The risk of detrimental change can be high for arid systems under many climate change scenarios (Herrick and Beh 2015). For a more complete discussion of soil change dynamics in arid and semi-arid systems see the section on grazing lands (Sect. 18.5).

Irrigation has been an important part of agriculture and cropping for decades, but has become increasingly widespread in the modern era, since 1800 (Michael 2008). Irrigation alters the distribution of salts by leaching soluble salts downward while evapotranspiration moves salts toward the surface. The resulting distribution of salts in the soil profile is determined by the crops grown, weather conditions, water quality, and water quantity applied as well as the drainage of excess irrigation water. Application of poor-quality irrigation water can lead to accumulations of sodium and trace elements (Dregne 2011; Grattan 2002). Most crop production on dry soils requires irrigation, but much of the USA's irrigation water is applied in semi-humid and humid areas (Fig. 18.4). The effects of irrigation can be very localized or regional (Ferguson and Maxwell 2012). See the discussion of irrigation in the Great Plains (Sect. 18.2.3).

\subsection{Soil Change in Wetlands}

While wetland soils are recognized as environmentally and ecologically important and legally protected in the USA, many USA wetland soils have been drained for agricultural production. The agricultural use of these potentially highly productive soils was recognized, and, in fact, encouraged by the Swamp and Overflowed Lands Act of 1850 (Wright 1907). Drainage districts were established in these states, and wetlands across the nation were drained. This resulted in significant management-induced soil change on these lands. Drainage of wetlands for agriculture in the Midwest may have resulted in SOC losses of 30-50 \% across the region (Baker et al. 2007). More recently, the value of wetland and hydric soils for ecosystem services have been recognized and attitudes about wetland drainage have changed (Gopal 2000). Wetlands are being managed for flood control, water quality, and wildlife habitat (Barbier et al. 2011; Brander et al. 2006; Zedler and Kercher 2005).

Wetland drainage is a direct alteration of the water table (e.g., James and Fenton 1993). As water tables were lowered through artificial drainage, peat or organic soils that 


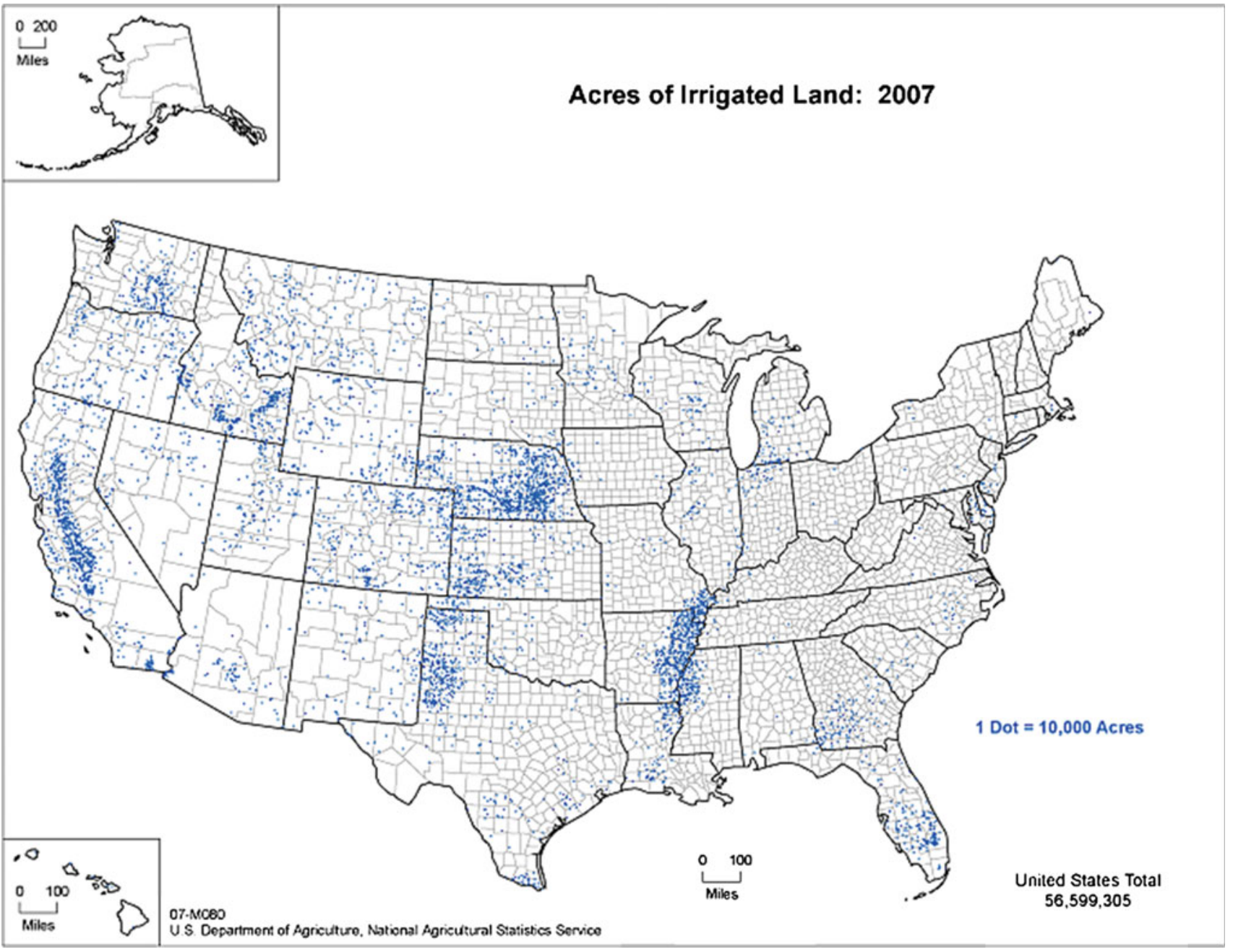

Fig. 18.4 Acres of irrigated land from the 2007 Census of Agriculture (USDA-National Agriculture Statistics Service (NASS) (2007)

had built up over time due to anaerobic conditions and slow decomposition were aerated and exposed to oxidation and wind erosion. In many places, this caused the soil to subside and become lower relative to set benchmarks (Parent et al.1982; Kohake et al. 2010). The majority of the subsidence is accounted for in gaseous as opposed to aqueous $\mathrm{CO}_{2}$ fluxes (Deverel and Rojstaczer 1996), suggesting that the losses are largely related to increased rates of organic matter decomposition. In some areas, subsidence occurred rapidly after the soil was first drained for agriculture and development. For example, in the California Sacramento-San Joaquin Delta, an estimated 55-80\% of the original peat layer was lost due to subsidence, which equates to a loss of 2900-5700 metric tons of organic C $\mathrm{ha}^{-1}$ (Drexler et al. 2009). Other soil changes associated with the drainage and tillage of organic matter-rich wetland soils include increased bulk density, decreased labile organic matter contents, and increased mineral content (Drexler et al. 2009; Shih et al. 1998).
Rates of organic soil subsidence have decreased over time. In 1950, Weir estimated that the rates of subsidence were $2.8-11.7 \mathrm{~cm} \mathrm{year}^{-1}$ in the California Delta (Weir 1950), and in the same time period, Stephens and Johnson (1951) estimated that the subsidence rate in the Everglades Agricultural Area in Florida was $3 \mathrm{~cm}^{-1}$ year $^{-1}$. By 1998, that rate had decreased to $1.4 \mathrm{~cm}$ year $^{-1}$ (Shih et al. 1998; Fig. 18.5). In the California Delta, the subsidence rate has decreased to $0.5-1.0 \mathrm{~cm} \mathrm{year}^{-1}$ (Deverel and Rojstaczer 1996). The reduction in subsidence rate is likely due to the maintenance of higher water tables in both regions. The Everglades Agricultural Area of Florida (EAA), during the first half of the twentieth century, was largely farmed for vegetables, and the perception was that water tables needed to be low. However, by the mid-twentieth century, more of the EAA was being farmed for sugarcane, a crop that is more tolerant of high water tables.

Not all wetlands have organic soils and wetland soils change for reasons other than drainage and subsidence. 
Fig. 18.5 Soil change through subsidence. This image shows the amount of subsidence that has occurred at the University of Florida's Everglades Research and Education Center, in Belle Glade, FL, since 1924 when a concrete post was driven into the organic soil so that it was level with the soil surface at the time. This photograph was taken in 2013 and represents about $1.8 \mathrm{~m}$ of soil loss. (Photograph credit: Alan Wright)

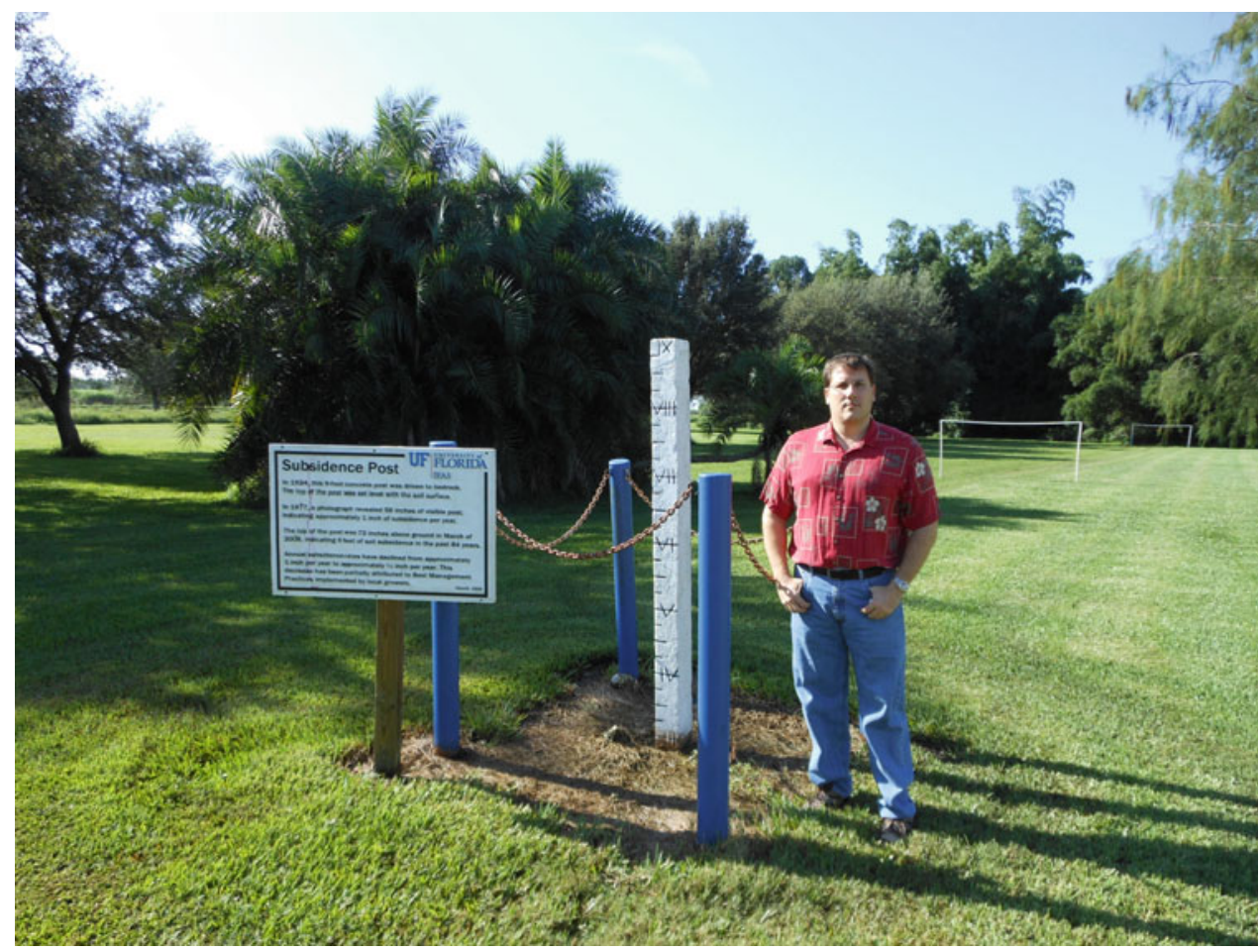

Riparian wetlands occur adjacent to streams and thus receive sediment deposition from the upstream watershed. Depressional wetlands receive deposition from a more limited area. Wetlands can retain high levels of nutrients and pollutants from water and sediments (Johnston 1991; Gilliam 1994), and these additions may alter the biogeochemistry within the wetland soils themselves (Morris 1991; Rokosch et al. 2009). Craft and Casey (2000) found that deposition in Georgia wetlands was dependent on past and current anthropogenic disturbance within the surrounding watershed. Freeland et al. (1999) found that there were higher rates of deposition in wetlands adjacent to cultivated fields in North Dakota. Sediments and nutrients deposited in wetlands impact the vegetation and hydrology of the systems (Mahaney et al. 2005; Preston et al. 2013).

Tidal or salt marshes occur along coasts and estuaries and have flooding characteristics determined by the tides (Adam 2002). Soils in these coastal marshes may be mineral or organic, and the salt balance in the marsh is determined by local geomorphology. They have low redox potential and are often very biologically active (Rabenhorst 2001; Seybold et al. 2002). Coastal marshes have been managed for forage and grazing for centuries (Gedan et al. 2009), and they are increasingly under heavy pressure from human development including pollution, introduced species, altered hydrology (including nutrient and sediment loadings), and climate change (Adam 2002; Scavia et al. 2002; Kirwan and Megonigal 2013). Many have been degraded and even destroyed by direct and indirect human management on the
Atlantic (Coverdale et al. 2014; Kearney et al. 2002), Gulf (Turner 2011), and Pacific coasts (Craft et al. 2003; Kennish 2001).

Kirwan et al. (2010) summarized the stability of coastal marshes as the balance between accretion and submergence where biological and physical factors interact to modify the marsh environment. Anthropogenic activity modifies marsh hydrology through changes in the quality, quantity, or distribution of water. On the gulf coast of Louisiana, DeLaune et al. (1983) found that the tidal marshes were being submerged due to decreases in sediment loads caused by changes in waterway management (such as dykes and levees for flood protection). Changes in water quality such as excess nutrient loading can also lead to coastal marsh degradation (Turner 2011; Deegan et al. 2012). Sea-level rise stresses the interaction between biophysical properties and can lead to soil submergence and weakening of marsh strength and integrity which eventually leads to erosion of the marsh into open water (Adam 2002; Kirwan and Megonigal 2013).

\subsection{Soil Change in Forest Lands}

While the most visible and dramatic changes in forested soils can occur when they are cleared for agriculture or plantations, forest management (silviculture) can induce remarkable levels of soil change (Binkley and Fisher 2012). Stand establishment (regeneration) and harvesting techniques can 
(a)

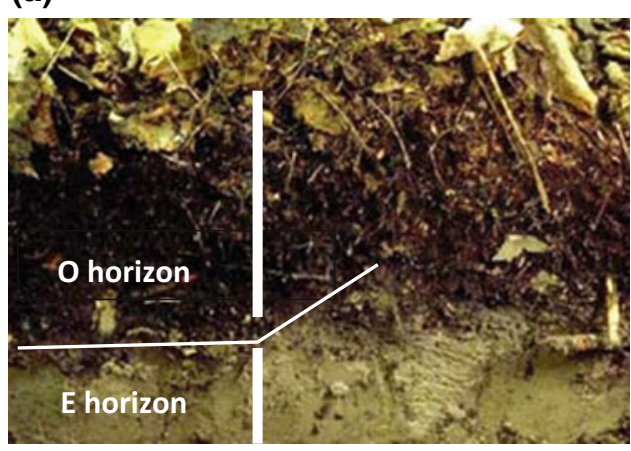

Fig. 18.6 Changes to $\mathrm{O}$ and $\mathrm{A}$ horizons caused by introduction of invasive earthworms. a Before earthworm invasion, a thick forest floor of organic materials (dark $\mathrm{O}$ horizon) on top of the mineral soil (light-colored E horizon) with a distinct boundary between the two. b After earthworm invasion, the forest floor has been replaced by a (b)

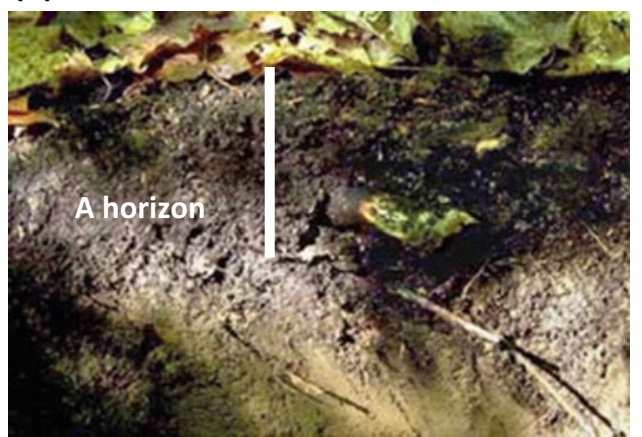

layer of thick black topsoil (A horizon) made mostly from earthworm casts. There are no longer distinct organic (O) and mineral horizons. (Photograph credit: Great Lakes Worm Watch http://www.nrri.umn. edu/worms/forest/soil.html) disturb the soil surface and can thus increase soil erosion and negatively impact soil productivity (Swanson et al. 1989; Megahan 1990). Loss of forest floor (litter and woody debris), compaction (increase in bulk density), and access routes may contribute to increased erosion in managed forests (Elliot et al. 1998; Grigal 2000). Due to the slow growth of most forest species, recovery from soil disturbance can take extended lengths of time (decades to centuries).

The most apparent soil change in forestland at the pedon scale takes place at the interface between air, forest floor, and soil. Many mechanical actions from harvesting disturb the soil surface inadvertently with trails, skids, and other physical impacts from heavy machinery. The soil surface may be deliberately disturbed through management techniques such as prescribed burns and scarification (exposing mineral soil) to improve forest seedling regeneration (Page-Dumroese et al. 1997). In southeastern forests, bedding radically alters the forest floor by mechanically creating raised beds to plant plantation seedlings. Physical disturbance may remove organic material, therefore altering bulk density and disrupting the nitrogen cycle as well as leading to accelerated soil erosion (Fox et al. 1986; Gent et al. 1984; Grigal 2000; Jandl et al. 2007; Jurgensen et al. 1997; Mclaughlin et al. 2000). Surface disruption can also cause lingering changes to soil biochemistry and microbial communities (Amaranthus et al. 1989; Hartmann et al. 2012).

In the eastern USA, forest clearing has created massive erosion and deposition events, which can be observed as multiple buried soils along terraces (Bierman et al. 2005). Forests in the northern portion of the USA may experience higher soil temperature and impaired soil gas exchange due to harvesting and site preparation (Ballard 2000). In the western USA, changes to fire regimes (through suppression, prevention, or more recently, prescribed burns) can cause changes in forest floor that may vary in duration due to soil and landscape variables as well as management actions (Certini 2005). These types of soil change can have impacts at watershed and larger scales such as stream quality and flooding from increased runoff (DeBano et al. 1998).

Some of the most widespread impacts of human management on forested soils are indirect. Soil acidification through industrial output (deposited across forests in the northeastern USA as acid rain) has caused alteration of chemical and biological processes in forest ecosystems (Robarge and Johnson 1992). This has been shown to lead to changes in forest productivity and species composition related to changes in $\mathrm{Al}$ concentrations and $\mathrm{pH}$ of the soil (Drohan and Sharpe 1997). The spread of introduced earthworms has altered the biological and structural systems of forest floors in northern USA hardwood forests (Fig. 18.6) Invasive earthworms consume $\mathrm{O}$ horizon material and leave behind castes that mix decomposed organic material and mineral soil. A horizons in these systems can be thickened with increased bulk density and altered $\mathrm{N}$ and $\mathrm{P}$ cycling (Hale et al. 2005). The presence of invasive earthworms has been shown to be correlated with anthropogenic activities such as recreation (fishing and cabins) and transportation (roads and trails) (Holdsworth et al. 2007). In the northwestern USA, current fire regime and past fire history have interacted to produce forests that may not be well suited to thrive or survive under future climate change scenarios (Whitlock et al. 2003).

\subsection{Soil Change in Grazing Lands}

Large ungulate grazing shapes ecosystems through herbivory (consumption of plant matter by ungulates), physical impact (hoof impact, wallowing, etc.), and deposition (urine, dung, and carcasses). Grazing lands, defined here as lands 
where grazing by domestic livestock is currently or has historically been a major land-use activity, are typically divided into two general types: (1) pasture lands, characterized by intensive management (e.g., irrigation and application of fertilizer and seed) and replacement of a native vegetation community with seeded forage; and (2) rangelands, which are characterized by low management inputs and retention of native vegetation communities. The management impacts on soils can differ dramatically between range and pasture lands; thus, it is a useful distinction for discussions of soil change.

In pasture systems, direct effects of grazing are additive to those caused by the direct impacts of management on soils. For example, seedbed preparation, seeding, and fertilization can cause soil change similar to those seen in croplands. Similarly, irrigation can change the growing environment and soil solution composition leading to increased plant production and altered carbon and nutrient dynamics. Soil changes due to pasture management include direct impact on the soil surface and changes in nutrient cycling due to species composition, animal deposition, and fertilizer inputs. Grazing may increase bulk density (Greenwood and McKenzie 2001), specifically in areas of concentrated hoof action (Tate et al. 2004), although sometimes less so than conversion to tilled cropland (Franzluebbers et al. 2000). In North Dakota, Liebig et al. (2006) found that pasture management (including stocking rate, species mix, and fertilizer treatment) changed soil bulk density, $\mathrm{pH}$, and nitrogen levels. In the southeastern USA, conversion of cropland to pasture has been shown to increase SOC content, but the depth distribution is unlikely to be equivalent to native systems (Franzluebbers et al. 2000). While soil degradation (loss of beneficial surface material and characteristics) in pasture lands is recognized as a potential result of poor pasture management, the exact mechanisms of these responses are not fully known (Bilotta et al. 2007). However, active management of pastureland can also provide opportunities to manage undesirable soil change (more so than in rangelands).

In rangelands, management options that effect soil change are more limited. Short-term (annual) options are typically only associated with animal management (timing, intensity, and duration of grazing). Although management of rangelands is usually not intensive, the impacts of domestic herbivores on these landscapes can be substantial. Cows (the most common grazer) have been proposed as an agent of geomorphic change by Trimble and Mendel (1995). Active degradation of western USA rangelands was particularly widespread and acute after the expansions of the railroads and prior to the Taylor Grazing Act of 1934. In a study using high alpine lakes of the southern Rocky Mountains, Neff et al. (2008) documented an increase in dust production by more than fourfold beginning in the mid- to late nineteenth century (Pacific Railway Act was signed in 1862) and subsequent decrease in the early to mid-1900s. This dust is sourced to the dry regions of northern Arizona and attributed to the removal of vegetation and disturbing of exposed soil surfaces by cattle (Neff et al. 2008). The impacts of grazing on soils are highly variable depending on the ecosystem, soil and management system in question, as well as the soil properties evaluated (Bilotta et al. 2007). In some instances (e.g., fertile soils in mesic environments), the effects of grazing on plant and soils can be gradual and readily reversible with minor adjustments to grazing strategies (Briske et al. 2003). However, in many areas, particularly drier regions (aridic moisture regimes) that are characterized by low and variable rainfall, sparse vegetation cover, and erosion-prone soils, poor grazing management can cause ecosystems to cross biophysical thresholds. In these instances, the changes to soils and vegetation persist when grazing pressure is reduced or eliminated and usually require active restoration (Briske et al. 2003).

Range improvement projects that use herbicide, fire, heavy equipment, or hand tools to manipulate rangeland vegetation communities are a common approach for improving wildlife habitat, increasing forage production, controlling fuels, or restoring post-fire landscapes in the western USA. The degree to which these activities affect soil change is primarily dependent on the amount that the soil is disturbed during implementation and project success in altering species composition (e.g., woody to herbaceous) or abundance. Woody species removal (in fuel treatments or for range improvements) can increase the amount of woody litter incorporated into soils (Ross et al. 2012). Treatments that increase herbaceous cover and productivity may be associated with a multitude of changes to soil quality (van Auken 2000). The use of heavy equipment for both removal of woody vegetation and application of seed disturbs the soil surface and can leave large areas susceptible to erosion by wind and water. For example, broad-scale soil disturbance associated with post-fire seeding treatments following the Milford Flat Fire in Central UT was associated with extreme wind erosion in the most sensitive landscape settings, resulting in rates of wind-driven sediment flux that rank among the highest ever recorded in North America (Miller et al. 2012). Furthermore, negative feedbacks between broad-scale soil destabilization and wind-driven saltating sands further hampered establishment of desired species in these aridic soils (Duniway et al. 2015). Indeed, direct manipulations of rangeland plant communities are more likely to be successful in more mesic soil systems than aridic (Knutson et al. 2014), suggesting desirable impacts on soil change and dynamic soil properties are much more likely in mesic than aridic soil systems.

In rangelands, soil change and changes in plant community composition and cover are often coupled. Grazing 
(a)

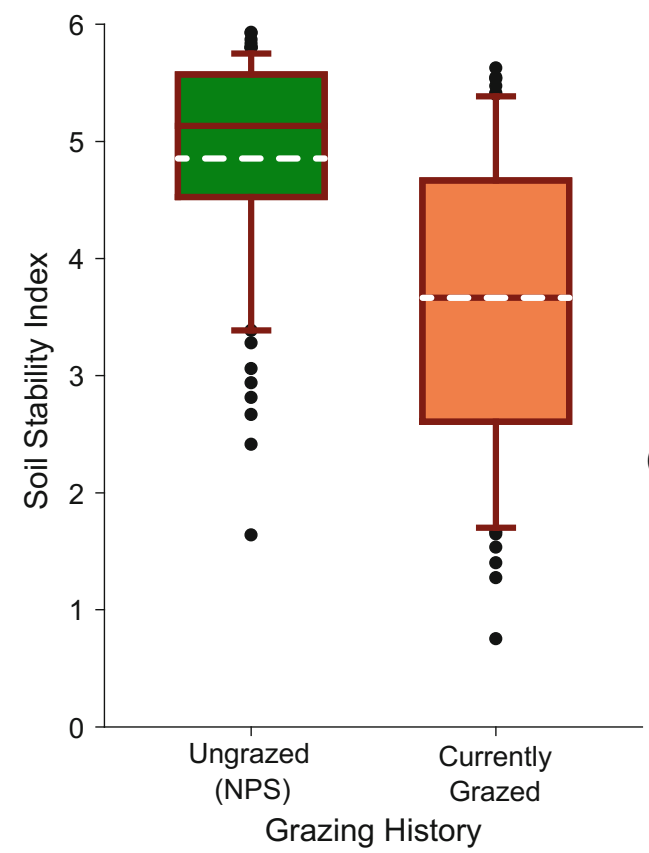

(b)

(c)
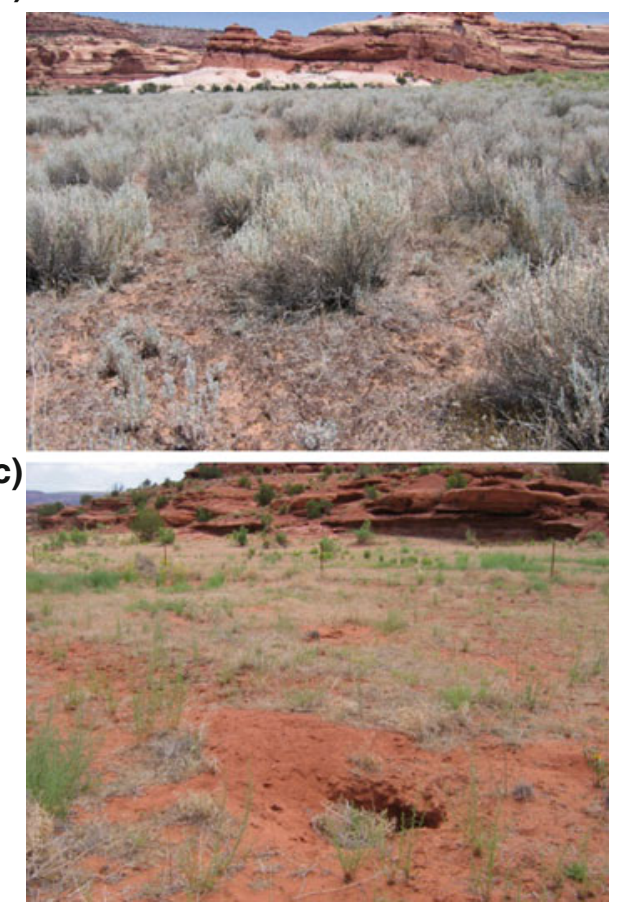

Fig. 18.7 Soil change caused by grazing: a Effects of grazing history on near surface soil aggregate stability from a rangeland setting in southeastern Utah, USA. Average aggregate stability is significantly greater in ungrazed than grazed pastures $(p<0.001)$ (aggregate stability collected following Herrick et al. 2001). Photographs showing b well-developed biological crust cover in a national park, compared to c heavily grazed area outside the park. Box plots show plot mean (white

alters the structure of plant communities by selectively grazing or disrupting growth and reproduction of some species (Augustine and McNaughton 1998; Belsky 1992; Cingolani et al. 2005). Grazing can also interact with woody, weedy, and invasive species by altering competitive interactions, effects on fire frequency (via effects on fine fuels), and seedling germination (MacDougall and Turkington 2005; DiTomaso 2000). Grazing alters carbon and nutrient cycling directly through removal of plant biomass reducing the amount of biomass that is returned to the soil as litter (Holland et al. 1992) and indirectly through changes in vegetation structure, composition, and growth (Biondini et al. 1998; McIntyre and Lavorel 2007).

Dynamic soil properties in semi-arid and arid rangelands are characteristically patchy, and understanding how soil quality soil quality varies spatially has emerged as an important indicator of range land health (Herrick 2000; Pyke et al. 2002). Some of the most important indicators of soil change are not simply plot averages but measures of vascular dashed horizontal line), median (solid horizontal line), 25th and 75th quantiles (lower and upper bounds of box), 10th and 90th percentile (whiskers), and outliers (black dots) aggregate stability values. Data are from 80 plots sampled within Canyonlands National Park (ungrazed for 40 years) and 65 plots in the surrounding private, state, and federal lands that are open to grazing (Miller et al. 2012). All sites were located on similar soils based on NRCS Ecological Site Classification

plant distribution, soil attributes both under plant canopies and in patches between plants. For example, the development of biological and physical soil crusts is common in the patches between plant canopies. Biological crusts (and physical crusts to some extent) can increase the stability of these exposed surfaces, lowering erodability by wind and water (Belnap and Gillette 1998; Belnap 2006). Direct hoof action by grazers disturbs soil surfaces, breaking up fragile crusts, and thereby greatly increasing soil erodability in areas heavily trafficked by grazers (Belnap and Eldridge 2003). Similarly, the development of water-stable soil aggregates will covary with both plant and crust cover, typically greater in perennial plant or crust patches than in bare interspaces (Fig. 18.7; Herrick et al. 2001). The patchy nature of arid and semi-arid rangelands has led to the development of semi-quantitative approaches for evaluating soil and site stability that explicitly accounts for spatial variability (e.g., Interpreting Indicators of Rangeland Health (Pellant et al. 2005) and Pedoderm and Pattern Classes (Burkett et al. 2011)). 


\subsection{Soil Change in Extreme Conditions}

Some of the most dramatic examples of soil change occur when sensitive soils or areas are mishandled or poorly managed. Acid sulfate soils undergo extreme (and negative) changes after they are exposed and oxidized. Cold soils are sensitive to heat and other human-induced environmental changes. Some land uses, such as strip-mining, alter the landscape entirely producing massive amounts of soil change. Extreme soil change is typically non-recoverable. Land-use options are limited by the impacts of past use and management.

\subsubsection{Acid Sulfate Soils}

An extreme example of management-induced soil change is the production of sulfuric acid in acid sulfate soils. In such soils, sulfuric acid is being produced (active), has been produced (post-active), or could be produced (potential). Potential acid sulfate soils are typically formed under anaerobic conditions in coastal or tidal sedimentary environments where iron sulfide minerals accumulate (Dent and Pons 1995). When these minerals oxidize, they produce sulfuric acid, which lowers soil $\mathrm{pH}$ to 3.5 or less, which is a level below which most plants will not grow. These minerals oxidize, and the soils become active acid sulfate soils through drainage, surface deposits of dredged material, or earth-moving associated with development, construction, and mining (Bradshaw 1997; Fanning 2006).

The Food and Agriculture Organization of the United Nations (FAO) suggests that there are 0.1 million ha of potential and active acid sulfate soils in North America, which is only a small proportion of the estimated world total of 12.6-18.1 million ha. (Andriesse and van Mensvoort 2006). Although they have not been formally mapped, there are several locations within the USA where the formation of sulfuric horizons (low $\mathrm{pH}$, evidence of oxidation of sulfide minerals) has been observed, such as dredged materials from the San Francisco Bay of California, the Baltimore Harbor in Maryland, the tidal Pocomoke River in Maryland, reclaimed marshland soils in Florida, clay landfill caps in New York and Maryland and exposed soil as a result of construction activities in Virginia (Grass et al. 1962; Calvert and Ford 1973; Fanning and Burch 1997; Demas et al. 2004, Fanning 2004).

\subsubsection{Management Impacts in Soils of Cold Climates}

Cold climate soils are those that formed in high latitudes or at high altitudes that have a mean annual soil temperature (at
$50 \mathrm{~cm}$ depth) of $\angle 8{ }^{\circ} \mathrm{C}$ (Ping 2005) and mean summer (June, July, August) soil temperature of $<15{ }^{\circ} \mathrm{C}$ (Soil Survey Staff 1999). About $16-18 \%$ of the USA consists of cold climate soils of which $<1 \%$ is farmland. Almost all of the cold soils (in the USA) are located in Alaska, most in the tundra and boreal forest ecoregions. Features of cold soils include permafrost (continuous and discontinuous), formation of ground ice, and cryoturbation from freeze-thaw cycles. Permafrost impedes soil drainage creating high moisture contents and can result in the accumulation of solutes in the active layer (Alekseev et al. 2003). Above the permafrost is the active layer (seasonally thawed layer), that can range from 0.2 to $5 \mathrm{~m}$ or more in thickness (Marchenko and Etzelmüller 2013). In a natural system, permafrost and ground ice are buffered or insulated by surface vegetation and surface organic layers ( $\mathrm{O}$ horizons). Removal of this buffer results in recession of the permafrost table and an increase in depth of the active layer. Once the thermal equilibrium is disrupted, increased thawing can result (Brown 1997).

Near Fairbanks Alaska, clearing of an area of natural boreal forest vegetation and removal of the 10-cm-thick surface organic layer resulted in a drop in the permafrost table from 1 to $5 \mathrm{~m}$ (Kallio and Rieger 1969). When ground ice melts, the surface topography is changed and increased melting can lead to major ground disturbances known as thermokarst (Fig. 18.8). Anthropogenic disturbances such as construction of roads, trails, airfields, trampling, and agriculture can have profound effects on the landscape due to subsidence and thermokarst over relatively short timescales (Nelson et al. 2002). Melting permafrost on ice-rich slopes can cause soil erosion and gullying (Brown 1997). Farming in cold soils leads to a thickening of the active layer (deeper permafrost), which results in changes in leaching, oxidation, and reduction as well as cryogenic processes (Ping 2005). Overgrazing and excessive trampling can result in disturbed or destroyed surface organic layers or surface vegetation cover, leading to permafrost melting and erosion (Forbes 1999; Ping 2005). Increased dust load associated with gravel roads and pads can alter tundra nutrient cycling and nutrient regimes (Moorhead et al. 1996) and has several ecological consequences (Walker and Everett 1987).

The active layer and upper permafrost can contain large quantities of organic $\mathrm{C}$ compared to soils in temperate ecosystems as a result of frost churning (Bockheim et al. 1999; Ping et al. 1997; Ping 2013; Tarnocai 2009). In the subarctic, land-use change has been found to increase soil temperatures by $4-5{ }^{\circ} \mathrm{C}$, lengthen the season of biological activity by $2-3$ weeks, and enhance plant residue decomposition by $25 \%$ (Grünzweig et al. 2003). Land-use change from forest to agricultural land results in increased $\mathrm{CO}_{2}$ emissions, but can be minimized by selecting relatively C-poor soils for land-use change and by implementing $\mathrm{C}$ 
Fig. 18.8 Aerial photograph of thermokarst in tundra on the North Slope of Alaska. The upper ice-rich permafrost is thawing and water draining, resulting in the settling and collapse of the surface. (Photograph credit: Cathy Seybold)

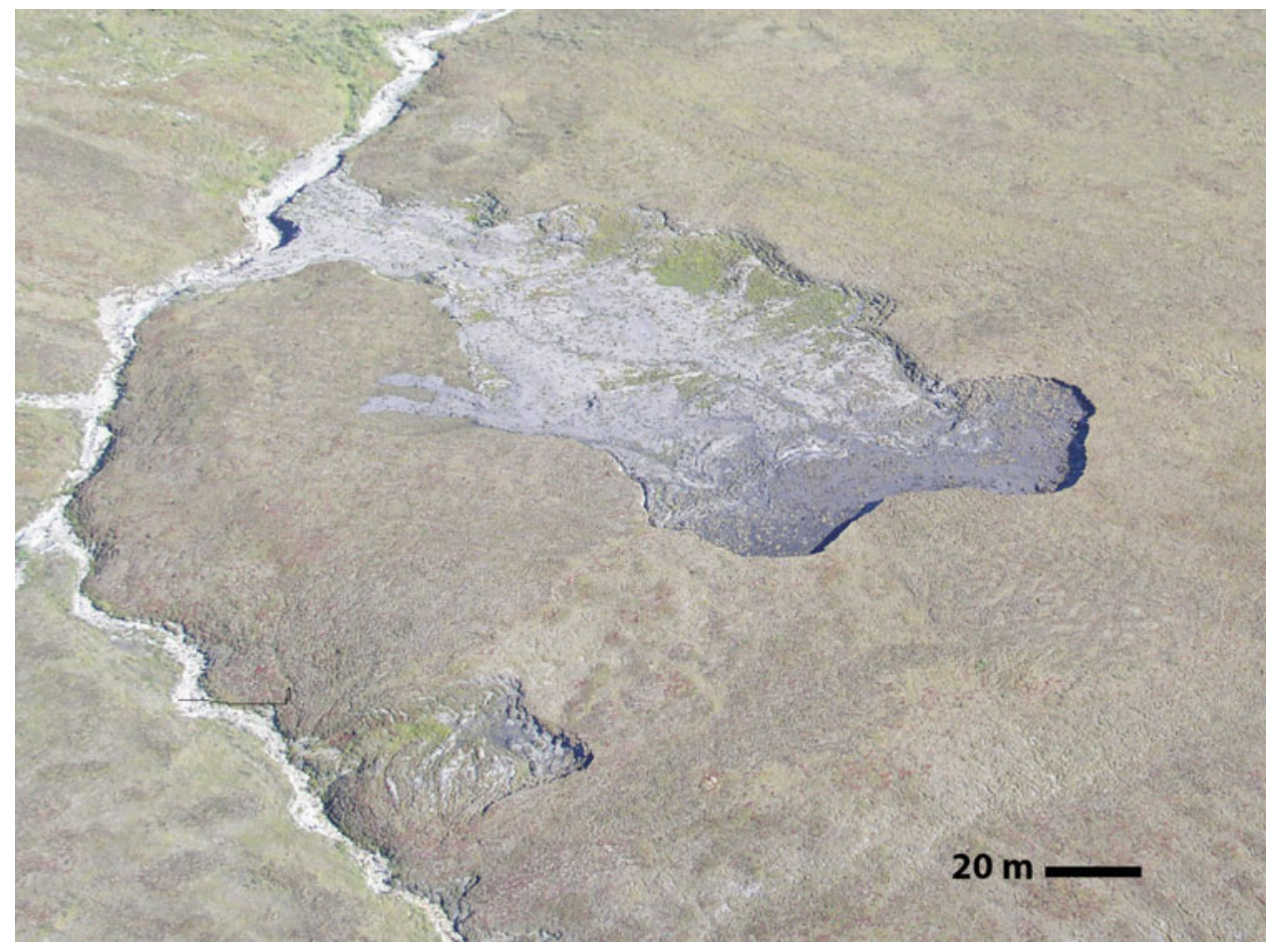

preservation management strategies (e.g., perennial crops, low tillage) (Grünzweig et al. 2004). Increases in the number of freeze-thaw cycles can decrease aggregate size distribution and can lower infiltration rates (Fouli et al. 2013). Conversation tillage options have been shown to be viable in Alaska to promote infiltration and conserve organic matter (Sharratt et al. 2006a; Sparrow et al. 2006). Zhang et al. (2012) found net $\mathrm{C}$ gains and improved soil quality after 18 years in the conservation reserve program (CRP), over that of native forest in subarctic Alaska. The CRP is a US government program where environmentally sensitive land is removed from agriculture production for a period of time.

\subsubsection{Impacts of Strip-Mining for Phosphates}

An example of extreme soil change is that caused by management associated with phosphate strip-mining as is done in Florida, North and South Carolina, Tennessee, Utah, Idaho, Montana, and Wyoming (USGS 2014a). Phosphorus mining began in the late 1800s and expanded in the 1900s in North and South Carolina, Tennessee, and Florida. The mining industry grew largely as a response to the increasing demand for phosphorus fertilizer by farmers in the southeast USA (Richter and Markewitz 2001). Today $85 \%$ of USA-mined phosphorus comes from mines in Florida and North Carolina, while the remainder comes from Idaho and Utah (USGS 2014b).
In the phosphorus mining regions in North Carolina and Florida, 3-15 $\mathrm{m}$ of overburden is stripped off to allow excavation of the phosphate-rich material below (Marion 1986). After excavation, the phosphate is separated from the soil and unconsolidated material leaving behind overburden fill, sand tailings, and clay-slime (Brown et al. 1992) each of which have different soil characteristics. Overburden fill tends to have characteristics most closely related to the native soils of the area, but they are mixed and spatially variable (Wallace and Best 1983). The native soils in the phosphate-mining region of Florida are Spodosols with a fine sand texture, low $\mathrm{pH}$, low cation exchange capacity (CEC), and low organic matter. The native soils of the phosphate-mining region of North Carolina are Ultisols with fine sandy loam surface texture, low $\mathrm{pH}$, and low CEC. The overburden fill sites are characterized by the mixing of many native soil horizons and tend to have finer surface textures, greater $\mathrm{CEC}$, higher water-holding capacity (WHC), and higher $\mathrm{pH}$ than nearby native soils (Hawkins 1973; Wilson and Hanlon 2012). Also, overburden fill surface horizon bulk density is usually higher and subsoil bulk density is usually lower than the natural soils (Gee et al. 1978; Chambers et al. 1994). Overburden fill sites can be suitable for agriculture or development.

Sand tailings are the quartz sands that have been separated from the clay and phosphate during the mining process. Phosphorus and calcium concentrations tend to be three to five times greater in these soils than those found in 
undisturbed or native soils (Davis et al. 1991), but the soils have low CEC, WHC, organic matter, $\mathrm{K}$, and micronutrients (Mislevy and Blue 1981) These sand tailings can be used for agriculture, but nutrients and WHC can be limiting. They are highly suitable for development as the sands are quite stable surfaces compared to the clay-slime settling areas (Wilson and Hanlon 2012). The final waste sediment from the phosphate-mining process is the clay-slime slurry, which is pumped to retention basins and allowed to dry. About $40 \%$ of phosphate-mined reclamation areas are clay-settling basins (Wilson and Hanlon 2012). The resulting soil textures of these sites are largely clay that is high in smectites and has high shrink swell potential (Hawkins 1973). They are heavy, sticky, and slow to dry, which makes them poorly suited for development, but they have been productive for agricultural crops (Mislevy et al. 1990).

In Florida, phosphate mining has impacted 526,000 ha., disturbing 2500 ha. annually, and 25-30\% of the lands impacted by phosphate mining are isolated or hydrologically connected wetlands (FDEP 2010). Although, reclaimed phosphate-mined land soils differ from native soils, soil development in created wetlands on overburden fill, and sand tailings mimics that of natural wetland soil formation; that is, organic matter accumulates, $\mathrm{C}: \mathrm{N}$ ratio decreases, and bulk density decreases with increasing wetland age (Nair et al. 2001).

\subsection{Conclusions}

Soil change is a general term that can apply to small localized disturbances and responses or to broad landscape scale disruptions. Human management impacts soil properties across all kinds of soils and land uses. Land-use conversion is often accompanied by soil change, but management decisions within individual land uses can have meaningful impacts on soil properties. Tillage has produced notable changes in soil physical structure and carbon cycles across the USA croplands. Wetland soils have been changed by drainage, sedimentation, and changes in sea level. Forest silviculture often results in changes to the forest floor and surface soil horizons. Grazing impacts are highly dependent on the specific conditions of a location and the management system in place, inputs, and disruptions. Soils interact with ecosystems through feedbacks with plants, animals, and water. Some systems are resistant to change, some are resilient and can recover after disruption, and still others will undergo catastrophic change when disturbed. Anthropogenic soil change should continue to be studied and assessed to allow for better quantification of the impacts on soil function and ecosystem services.

\section{References}

Adam P (2002) Saltmarshes in a time of change. Environ Conserv 29 (01):39-61

Alekseev A, Alekseeva T, Ostroumov V, Siegert C, Gradusov B (2003) Mineral transformations in permafrost-affected soils, North Kolyma Lowland, Russia. Soil Sci Soc Am J 67:596-605

Amaranthus MP, Trappe JM, Molina RJ (1989) Long-term forest productivity and the living soil. In: Perry DA, Meurisse R, Thomas B, Miller R, Boyle J, Means J, Perry CR, Powers RF (eds) Maintaining the long-term productivity of Pacific Northwest Forest ecosystems. Timber Press, Portland, pp 36-52

Amundson R, Jenny H (1991) The place of humans in the state factor theory of ecosystems and their soils. Soil Sci 151:99-109. doi:10. 1097/00010694-199101000-00012

Andriesse W, van Mensvoort MEF (2006) Acid sulfate soils: distribution and extent. In: Lal R (ed) Encyclopedia of soil science, 2nd edn. Taylor and Francis Group, New York

Archer S, Boutton TW, Hibbard KA (2001) Trees in grasslands: biogeochemical consequences of woody plant expansion. In: Schultze ED, Harrison SP, Heimann M, Hollan EA, Lloyd J, Prentice IC, Schimel D (eds) Global biogeochemical cycles in the climate system. Academic Press, San Diego, pp 115-137

Arnold RW, Szabolcs I, Targulian VO (eds) (1990) Global soil change. Report of an IIASA-ISSS-UNEP task force on the role of soil in global change. International Institute for Applied System Analysis, Laxenburg, Austria

Augustine DJ, McNaughton SJ (1998) Ungulate effects on the functional species composition of plant communities: herbivore selectivity and plant tolerance. J Wildl Manag 1998:1165-1183

Baker JM, Ochsner TE, Venterea RT, Griffis TJ (2007) Tillage and soil carbon sequestration - what do we really know? Agric Ecosyst Environ 118(1):1-5

Ballard TM (2000) Impacts of forest management on northern forest soils. For Ecol Manag 133(1):37-42

Barbier EB, Hacker SD, Kennedy C, Koch EW, Stier AC, Silliman BR (2011) The value of estuarine and coastal ecosystem services. Ecol Monogr 81(2):169-193

Beach T (1994) The fate of eroded soil: sediment sinks and sediment budgets of agrarian landscapes in southern Minnesota, 1851-1988. Ann Assoc Am Geogr 84(1):5-28

Bellemare J, Motzkin G, Foster DR (2002) Legacies of the agricultural past in the forested present: an assessment of historical land-use effects on rich mesic forests. J Biogeogr 29:1401-1420

Belnap J (2006) The potential roles of biological soil crusts in dryland hydrologic cycles. Hydrol Process 20(15):3159-3178

Belnap J, Eldridge D (2003) Disturbance and recovery of biological soil crusts. Biological soil crusts: structure, function, and management. Springer, Berlin, pp 363-383

Belnap J, Gillette DA (1998) Vulnerability of desert biological soil crusts to wind erosion: the influences of crust development, soil texture, and disturbance. J Arid Environ 39(2):133-142

Belsky AJ (1992) Effects of grazing, competition, disturbance and fire on species composition and diversity in grassland communities. J Veg Sci 3(2):187-200

Bennie AT (1990) Growth and mechanical impedance. In: Waisel Y, Eshel A, Kafkafi U (eds) Plant roots. The hidden half. Marcel Dekker, New York, pp 393-414

Bidwell OW, Hole FD (1965) Man as a factor of soil formation. Soil Sci 99(1):65-72

Bierman PR, Howe J, Stanley-Mann E, Peabody M, Hilke J, Massey CA (2005) Old images record landscape change through time. GSA Today 15(4):1-6. doi:10.1130/1052-5173(2005)015 
Bilotta GS, Brazier RE, Haygarth PM (2007) The impacts of grazing animals on the quality of soils, vegetation, and surface waters in intensively managed grasslands. Adv Agron 94:237-280

Binkley D, Fisher R (2012) Dynamics of forest soils. In: Binkley D, Fisher R (eds) Ecology and management of forest soils. Wiley, London, pp 189-288

Biondini ME, Patton BD, Nyren PE (1998) Grazing intensity and ecosystem processes in a northern mixed-grass prairie, USA. Ecol Appl 8:469-479

Blanco-Canqui H, Stone LR, Schlegel J, Lyon DL, Vigil MF, Mikha MM, Stahlman PW, Rice CW (2009) No-till induced increase in organic carbon reduces maximum bulk density of soils. Soil Sci Soc Am J 73(6):1871-1879

Blois JL, Williams JW, Fitzpatrick MC, Jackson ST, Ferrier S (2013) Space can substitute for time in predicting climate-change effects on biodiversity. Proc Natl Acad Sci 110(23):9374-9379

Bockheim JG, Everett LR, Hinkel KM, Nelson FE, Brown J (1999) Soil organic carbon storage and distribution in arctic tundra, Barrow, Alaska. Soil Sci Soc Am J 63:934-940

Bordovsky DG, Choudhary M, Gerard CJ (1999) Effect of tillage, cropping, and residue management on soil properties in the Texas rolling plains. Soil Sci 164:331-340

Bradshaw A (1997) Restoration of mined lands-using natural processes. Ecol Eng 8:255-269

Brander LM, Florax RJ, Vermaat JE (2006) The empirics of wetland valuation: a comprehensive summary and a meta-analysis of the literature. Environ Resource Econ 33(2):223-250

Briske DD, Fuhlendorf SD, Smeins FE (2003) Vegetation dynamics on rangelands: a critique of the current paradigms. J Appl Ecol 40 (4):601-614

Bronick CJ, Lal R (2005) Soil structure and management: a review. Geoderma 124:3-22

Brown MT, Tighe RE, McClanahan TR, Wolfe RW (1992) Landscape reclamation at a central Florida phosphate mine. Ecol Eng 1:323354

Brown JR (1993) Sanborn field: a capsule of scientific agricultural history in central Missouri. Missouri Agric. Experiment Station, Columbia

Brown J (1997) Disturbance and recovery of permafrost terrain. In: Crawford RMM (ed) Disturbance and recovery in Arctic Lands. Kluwer Academic, Dordrecht, pp 167-178

Burkett LM, Bestelmeyer BT, Tugel AJ (2011) A field guide to pedoderm and pattern classes. Agriculture handbook, vol 1. http:// jornada.nmsu.edu/files/FieldGuidePedodermPattern.pdf. Accessed 15 May 2015

Calvert DV, Ford HW (1973) Chemical properties of acid sulfate soils recently reclaimed from Florida marshland. Soil Sci Soc Am Proc 37:367-371

Cambardella CA, Elliott ET (1992) Particulate soil organic-matter changes across a grassland cultivation sequence. Soil Sci Soc Am J 56:777-783. doi:10.2136/sssaj1992.03615995005600030017x

Certini G (2005) Effects of fire on properties of forest soils: a review. Oecologia 143(1):1-10

Chambers JC, Brown RW, Williams BD (1994) Reclamation success on Idaho's phosphate mines. Restor Ecol 2(1):4-16

Cingolani AM, Noy-Meir I, Díaz S (2005) Grazing effects on rangeland diversity: a synthesis of contemporary models. Ecol Appl 15 (2):757-773

Cook BI, Miller RL, Seager R (2009) Amplification of the North American "Dust Bowl" drought through human-induced land degradation. Proc Natl Acad Sci 106(13):4997-5001

Costanza R, d'Arge R, de Groot R, Farber S, Grasso M, Hannon B, Limburg K, Naeem S, Paruelo J, O’Neill RV, Paruelo J, Raskin R, Sutton P, van den Belt M (1997) The value of the world's ecosystem services and natural capital. Nature 387:253-260
Coverdale TC, Brisson CP, Young W, Yin SF, Donnelly JP, Bertness MD (2014) Indirect human impacts reverse centuries of carbon sequestration and salt marsh accretion. PLoS One 9(3): e93296

Craft CB, Casey WP (2000) Sediment and nutrient accumulation in floodplain and depressional freshwater wetlands of Georgia, USA. Wetlands 20(2):323-332

Craft CB, Megonigal P, Broome S, Stevenson J, Freese R, Cornell J, Zheng J, Sacco J (2003) The pace of ecosystem development of constructed Spartina alterniflora marshes. Ecol Appl 13(5):14171432

Daniels RB, Gilliam JW, Cassel DK, Nelson LA (1985) Soil erosion class and landscape position in the North Carolina Piedmont. Soil Sci Soc Am J 49(4):991-995

Dao TH (1993) Tillage and winter wheat residue management effects on water infiltration and storage. Soil Sci Soc Am J 57(6):15861595

Davis M, Brown MT, Doherty S, Tighe RE (1991) Techniques and guidelines for reclamation of phosphate mined lands. In Brown MT, Tighe RE (eds) Florida Institute Phosphate Research publication no. 03-044-095

DeBano LF, Neary DG, Folliott PF (1998) Fire effects on ecosystems. Wiley, London

Deegan LA, Johnson DS, Warren RS, Peterson BJ, Fleeger JW, Fagherazzi S, Wollheim WM (2012) Coastal eutrophication as a driver of salt marsh loss. Nature 490(7420):388-392

DeLaune RD, Baumann RH, Gosselink JG (1983) Relationships among vertical accretion, coastal submergence, and erosion in a Louisiana Gulf Coast marsh. J Sediment Res 53:1

Demas SY, Halt AM, Fanning DC, Rabenhorst MC, Dzantor EK (2004) Acid sulfate soils in dredged materials from tidal Pocomoke Sound in Somerset County, MD, USA. Aust J Soil Res 42:537-544

Dent DL, Pons LJ (1995) A world perspective on acid sulphate soils. Geoderma 67(3-4):263-276

Derr M (1998) Some kind of paradise: a chronicle of man and the land in Florida. University Press of Florida, Gainesville

Deverel S, Rojstaczer S (1996) Subsidence of agricultural lands in the Sacramento-San Joaquin Delta, California: role of aqueous and gaseous carbon fluxes. Water Resour Res 32(8):2359-2367

DiTomaso JM (2000) Invasive weeds in rangelands: species, impacts, and management. Weed Sci 48(2):55-265

Doran JW (1980) Soil microbial and biochemical changes associated with reduced tillage. Soil Sci Soc Am J 44(4):765-771

Doran JW, Parkin TB (1994) Defining and assessing soil quality. SSSA Spec Publ 35:3-3

Dregne HE (2011) Soils of arid regions. Elsevier, Amsterdam

Drexler JZ, Fontaine C, Deveret S (2009) The legacy of wetland drainage on the remaining peat in the Sacramento-San Joaquin Delta, California, USA. Wetlands 29(1):372-386

Drohan JR, Sharpe WE (1997) Long-term changes in forest soil acidity in Pennsylvania, USA. Water Air Soil Pollut 95(1-4):299-311

Duniway MC, Palmquist E, Miller ME (2015) Evaluating rehabilitation efforts following the Milford Flat Fire: successes, failures, and controlling factors. Ecosphere 6:art80

Ehlers W, Köpke U, Hesse F, Böhm W (1983) Penetration resistance and root growth of oats in tilled and untilled loess soil. Soil Tillage Res 3(3):261-275

Elliot WJ, Page-Dumroese D, Robichaud PR (1998) The effects of forest management on erosion and soil productivity. In: Lal $\mathrm{R}$ (ed) Soil quality and soil erosion. Soil and Water Conservation Society, CRC Press LLC, Boca Raton, p 195

Fanning D (2004) Acid sulfate soils. In: Muckel GB (ed) Understanding soil risks and hazards: using soil to identify areas with risks and hazards to human life and property. United States Department of Agriculture, USA 
Fanning D (2006) Acid sulfate soils. In: Lal R (ed) Encyclopedia of soil science, 2nd edn. Taylor and Francis Group, New York

Fanning D, Burch SN (1997) Acid sulfate soils and some associated environmental problems. Adv Geoecol 30:145-158

FDEP (2010) Rate of reclamation report. Florida Department of Environmental Protection. http://www.dep.state.fl.us/water/mines/ docs/2010ror.pdf. Accessed 1 July 2014

Fenton TE (2012) The impact of erosion on the classification of Mollisols in Iowa. Can J Soil Sci 92(3):413-418

Ferguson IM, Maxwell RM (2012) Human impacts on terrestrial hydrology: climate change versus pumping and irrigation. Environ Res Lett 7(4):044022

Forbes BC (1999) Land use and climate change on the Yamal Peninsula of north-west Siberia: some ecological and socio-economic implications. Polar Res 18:367-373

Fouli Y, Cade-Menum BJ, Cutforth HW (2013) Freeze thaw cycles and soil water content effects on infiltration rate of three Saskatchewan soils. Can J Soil Sci 93:485-496

Fox TR, Burger JA, Kreh RW (1986) Effects of site preparation on nitrogen dynamics in the southern Piedmont. For Ecol Manag 15 (4):241-256

Franzluebbers AJ, Stuedemann JA, Schomberg HH, Wilkinson SR (2000) Soil organic C and N pools under long-term pasture management in the Southern Piedmont USA. Soil Biol Biochem 32 (4):469-478

Freeland JA, Richardson JL, Foss LA (1999) Soil indicators of agricultural impacts on northern prairie wetlands: Cottonwood Lake Research Area, North Dakota, USA. Wetlands 19(1):56-64

Froede CR Jr, Williams EL (2004) The origin, development, and eventual consolidation of the canyons comprising Providence Canyon State Park Stewart County, Georgia. Southeast Geol 43 (1):39-50

Gedan K, Silliman BR, Bertness MD (2009) Centuries of human-driven change in salt marsh ecosystems. Mar Sci 1:117-141

Gee GW, Bauer A, Decker RS (1978) Physical analyses of overburden materials and mine land soils. Reclamation of drastically disturbed lands. American Society of Agronomy, Madison, pp 665-686

Gent JA, Ballard R, Hassan AE, Cassel DK (1984) Impact of harvesting and site preparation on physical properties of Piedmont forest soils. Soil Sci Soc Am J 48(1):173-177

Gilliam JW (1994) Riparian wetlands and water quality. J Environ Qual 23(5):896-900

Gopal B (2000) Wetlands and agriculture: Are we heading for confrontation or conservation. http://www.srs.fs.usda.gov/pubs/ 20153/. Accessed 14 Jan 2015

Goudie AS (2013) The human impact on the natural environment: past, present, and future. Wiley, London

Goudie AS, Middleton NJ (1992) The changing frequency of dust storms through time. Clim Change 20(3):197-225

Grass LB, Aronovici VS, Mucket DN (1962) Some chemical characteristics of submerged and reclaimed sediments of the San Francisco Bay System. Proc Soil Sci Soc Am 26:453-455

Grattan S (ed) (2002) Irrigation water salinity and crop production. UCANR Publications

Gray LC (1933) History of agriculture in the southern United States to 1860. The Carnegie Institution, Washington

Greenwood KL, McKenzie BM (2001) Grazing effects on soil physical properties and the consequences for pastures: a review. Anim Prod Sci 41(8):1231-1250

Grigal DF (2000) Effects of extensive forest management on soil productivity. For Ecol Manag 138(1):167-185

Grünzweig JM, Stephen D, Sparrow S, Yakir D, Chapin FS III (2004) Impact of agricultural land-use change on carbon storage in boreal Alaska. Glob Change Biol 10:452-472
Grünzweig JM, Sparrow SD, Chapin FS III (2003) Impact of forest conversion to agriculture on carbon and nitrogen mineralization in subarctic Alaska. Biogeochemistry 64:271-296

Guzman J, Al-Kaisi M (2010) Soil carbon dynamics and carbon budget of newly reconstructed tall-grass prairies in south central Iowa. J Environ Qual 39:136-146

Hale CM, Frelich LE, Reich PR, Pastor J (2005) Effects of European earthworm invasion on soil characteristics in northern hardwood forests of Minnesota, USA. Ecosystems 8:911-927

Hall SJ, Trujillo J, Nakase D, Strawhacker C, Kruse-Peeples M, Schaafsma H, Briggs J (2013) Legacies of prehistoric agricultural practices within plant and soil properties across an arid ecosystem. Ecosystems 16(7):1273-1293

Hansen ZK, Libecap GD (2003) Small farms, externalities, and the Dust Bowl of the 1930s (No. w10055). National Bureau of Economic Research

Hartman MD, Merchant ER, Parton WJ, Gutmann MP, Lutz SM, Williams SA (2011) Impact of historical land-use changes on greenhouse gas exchange in the US Great Plains, 1883-2003. Ecol Appl 21(4):1105-1119

Hartmann M, Howes CG, Van Insberghe D, Yu H, Bachar D, Christen R, Nilsson R, Hallam SJ, Mohn WW (2012) Significant and persistent impact of timber harvesting on soil microbial communities in Northern coniferous forests. ISME J 6(12):21992218

Hawkins GJ (1973) Physical chemical, and mineralogical properties of phosphatic clay slimes from the bone valley formation. Master's thesis, University of Florida

Herrick JE (2000) Soil quality: an indicator of sustainable land management. Appl Soil Ecol 15(1):75-83

Herrick JE, Beh A (2015) A risk-based strategy for climate change adaptation in dryland systems based on an understanding of potential production, soil resistance and resilience, and social stability. Sustainable intensification to advance food security and enhance climate resilience in Africa. Springer, Berlin, pp 407-424

Herrick JE, Whitford WG, De Soyza AG, Van Zee JW, Havstad KM, Seybold CA, Walton M (2001) Field soil aggregate stability kit for soil quality and rangeland health evaluations. Catena 44(1):27-35

Hilgard EW (1860) Report on the geology and agriculture of the state of Mississippi. E. Barksdale, Jackson

Hobbie JE, Carpenter SR, Grimm NB, Gosz JR, Seastedt TR (2003) The US long term ecological research program. Bioscience 53:2132

Holdsworth AR, Frelich LE, Reich PB (2007) Effects of earthworm invasion on plant species richness in northern hardwood forests. Conserv Biol 21:997-1008

Holland EA, Parton WJ, Detling JK, Coppock DL (1992) Physiological responses of plant populations to herbivory and their consequences for ecosystem nutrient flow. Am Nat 140(4):685-706

Homburg JA, Sandor JA (2011) Anthropogenic effects on soil quality of ancient agricultural systems of the American Southwest. Catena 85(2):144-154

Hornbeck R (2009) The enduring impact of the American Dust Bowl: short and long-run adjustments to environmental catastrophe (No. w15605). National Bureau of Economic Research

Hubbs MD, Reeves DW, Mitchell CC (1998) Measuring soil quality on the 'old rotation'. Special reports-University of Arkansas Agricultural Experiment Station, vol 186, pp 50-54

Hyatt JA, Gilbert R (2000) Lacustrine sedimentary record of human-induced gully erosion and land use change at Providence Canyon, southwest Georgia, USA. J Paleolimnol 23:421-438

Indorante SJ, Kabrick JM, Lee BD, Maatta JM (2014) Quantifying soil profile change caused by land use in Central Missouri Loess Hillslopes. Soil Sci Soc Am J 78(1):225-237 
Izaurralde RC, Williams JR, McGill WB, Rosenberg NJ, Jakas MC (2006) Simulating soil C dynamics with EPIC: model description and testing against long-term data. Ecol Model 192:362-384

James HR, Fenton TE (1993) Water tables in paired artificially drained and undrained soil catenas in Iowa. Soil Sci Soc Am J 57(3):774781

Jandl R, Lindner M, Vesterdal L, Bauwens B, Baritz R, Hagedorn F, Johnson DW, Minkkinen K, Byrne KA (2007) How strongly can forest management influence soil carbon sequestration? Geoderma 137(3):253-268

Jenny H (1980) The soil resource, origin and behavior. Springer, New York. ISBN 0-387-90453-X

Jangid K, Williams MA, Franzluebbers AJ, Schmidt TM, Coleman DC, Whitman WB (2011) Land-use history has a stronger impact on soil microbial community composition than above ground vegetation and soil properties. Soil Biol Biochem 43(10):2184-2193

Johnson WC, Cantwell HD, Dean TA (1980) The impact of agricultural settlement on Canadian Sandy Creek, Oklahoma. In: Proceedings of the Oklahoma Academy of Science, vol 60

Johnston CA (1991) Sediment and nutrient retention by freshwater wetlands: effects on surface water quality. Crit Rev Environ Sci Technol 21(5-6):491-565

Jurgensen MF, Harvey AE, Graham RT, Page-Dumroese DS, Tonn JR, Larsen MJ, Jain TB (1997) Review article: Impacts of timber harvesting on soil organic matter, nitrogen, productivity, and health of inland northwest forests. For Sci 43(2):234-251

Kallio A, Rieger S (1969) Recession of permafrost in a cultivated soil of interior Alaska. Soil Sci Soc Am J 33(3):430-432

Karlen DL, Mausbach MJ, Doran JW, Cline RG, Harris RF, Schuman GE (1997) Soil quality: a concept, definition and framework for evaluation. Soil Sci Soc Am J 61:4-10. doi:10.2136/sssaj1997. $03615995006100010001 \mathrm{x}$

Kearney MS, Rogers AS, Townshend JR, Rizzo E, Stutzer D, Stevenson J, Sundborg K (2002) Landsat imagery shows decline of coastal marshes in Chesapeake and Delaware Bays. Eos Trans Am Geophys Union 83(16):173-178

Kelly RH, Parto WJ, Crocker GJ, Grace PR, Klfre J, Körschens M, Poulton PR, Richter DD (1997) Simulating trends in soil organic carbon in long-term experiments using the century model. Geoderma 81:75-90

Kennish MJ (2001) Coastal salt marsh systems in the US: a review of anthropogenic impacts. J Coast Res 17:731-748

Kirwan ML, Guntenspergen D, Alpaos A, Morris JR, Mudd SM, Temmerman S (2010) Limits on the adaptability of coastal marshes to rising sea level. Geophys Res Lett 37:L23401

Kirwan ML, Megonigal JP (2013) Tidal wetland stability in the face of human impacts and sea-level rise. Nature 504:53-60

Kladivko E (2001) Tillage systems and soil ecology. Soil Tillage Res 61(1-2):61-76. doi:10.1016/S0167-1987(01)00179-9

Knutson KC, Pyke DA, Wirth TA, Arkle RS, Pilliod DS, Brooks ML, Chambers JC, Grace JB (2014) Long-term effects of seeding after wildfire on vegetation in Great Basin shrubland ecosystems. J Appl Ecol 51:1414-1424

Kohake DJ, Hagen LJ, Skidmore EL (2010) Wind erodibility of organic soils. Soil Sci Soc Am J 74:250-257

Konen ME (1999) Human impacts on soils and geomorphic processes on the Des Moines Lobe. Iowa State University, Iowa

Lal R (1993) Tillage effects on soil degradation, soil resilience, soil quality, and sustainability. Soil Tillage Res 27:1-8

Lampurlanés J, Cantero-Martínez C (2003) Soil bulk density and penetration resistance under different tillage and crop management systems and their relationship with barley root growth. Agron J 95 (3):526-536
Lawrence GB, Fernandez JJ, Richter DD, Ross DS, Hazlett PW, Bailey SW, Ouimet R, Warby RAF, Johnson AH, Lin HS, Kaste JM, Lapenis AG, Sullivan TJ (2013) Measuring environmental change in forest ecosystems by repeated soil sampling: a North American perspective. J Environ Qual 42:623-639

Levi MR, Shaw JN, Wood CW, Hermann SM, Carter EA, Feng Y (2010) Land management effects on near-surface soil properties of southeastern US coastal plain Kandiudults. Soil Sci Soc Am J 74 (1):258-271

Liebig MA, Gross JR, Kronberg SL, Hanson JD, Frank AB, Phillips RL (2006) Soil response to long-term grazing in the northern Great Plains of North America. Agric Ecosyst Environ 115 (1):270-276

Lindbo DL, Moebius-Clune B, Hatfield J, et al (2014) Creating common ground: activities of the soil health dialog workgroup. In: EGU general assembly conference abstracts, vol 16, p 14555. http://adsabs. harvard.edu/abs/2014EGUGA.1614555L. Accessed 30 July 2014

Lowrance R, Altier LS, Williams RG, Inamdar SP, Sheridan JM, Bosch DD, Hubbard RK, Thomas DL (2000) REMM: the riparian ecosystem management model. J Soil Water Conserv 55(1):27-34

Lueking MA, Schepers JS (1985) Changes in soil carbon and nitrogen due to irrigation development in Nebraska's Sandhills soils. Soil Sci Soc Am J 49:626-630

MacDougall AS, Turkington R (2005) Are invasive species the drivers or passengers of change in degraded ecosystems? Ecology 86 (1):42-55

Mahaney WM, Wardrop DH, Brooks RP (2005) Impacts of sedimentation and nitrogen enrichment on wetland plant community development. Plant Ecol 175(2):227-243

Marchenko S, Etzelmüller B (2013) Permafrost: formation and distribution, thermal and mechanical properties. In: Shroder J (ed) Giardini R, Harbor J (eds) Treatise on geomorphology. Glacial and periglacial geomorphology, vol 8. Academic Press, San Diego, pp 202-222

Marion WR (1986) Phosphate mining regulations, reclamation, and revegetation. Florida Institute of Phosphate Research, Bartow, FL. Publication no. 03-043-040

McIntyre S, Lavorel S (2007) A conceptual model of land use effects on the structure and function of herbaceous vegetation. Agric Ecosyst Environ 119(1):11-21

McLauchlan K (2006) The nature and longevity of agricultural impacts on soil carbon and nutrients: a review. Ecosystems 9(8):1364-1382

McLaughlin JW, Gale MR, Jurgensen MF, Trettin CC (2000) Soil organic matter and nitrogen cycling in response to harvesting, mechanical site preparation, and fertilization in a wetland with a mineral substrate. For Ecol Manag 129(1):7-23

McVay KA, Budde JA, Fabrizzi K, Mikha MM, Rice CW, Schlegel AJ, Peterson DE, Sweeney DW, Thompson C (2006) Management effects on soil physical properties in long-term tillage studies in Kansas. Soil Sci Soc Am J 70:434-438

Megahan WF (1990) Erosion and site productivity in western Montane forest ecosystems. In: Harvey AE, Neuenschwander LG (eds) Proceedings of the management and productivity of Western Montane forest soils, Boise, ID, April 10-12, 1990. USDA Forest Service General Technical Report INT-280, pp 146-150

Michael AM (2008) Irrigation: theory and practice. Vikas Publishing House Pvt Ltd, India

Mikha MM, Vigil MF, Benjamin JG (2012) Long-term tillage impacts on soil aggregation and carbon dynamics under wheat-fallow in the central Great Plains. Soil Sci Soc Am J 77:594-605

Miller ME, Bowker MA, Reynolds RL, Goldstein HL (2012) Post-fire land treatments and wind erosion-lessons from the Milford Flat Fire, UT, USA. Aeol Res 7:29-44 
Mislevy P, Blue WG (1981) Reclamation of quartz sand-tailings from phosphate mining: I. Tropical forage grasses. J Environ Qual 10(4):449-453

Mislevy P, Blue WG, Roessler CE (1990) Productivity of clay tailings from phosphate mining: II. Forage crops. J Environ Qual 19:694700

Mitchell CC, Delaney DP, Balkcom KS (2008) A historical summary of Alabama's old rotation (circa 1896): the world's oldest, continuous cotton experiment. Agron J 100(5):1493-1498

Monger HC, Bestelmeyer BT (2006) The soil-geomorphic template and biotic change in arid and semi-arid ecosystems. J Arid Environ 65:207-218

Moorhead DL, Linkins AE, Everett KR (1996) Road dust alters extracellular enzyme activities in tussock tundra soils, Alaska, USA Arct Alp Res 28(3):346-351

Morgan RPC (2009) Soil erosion and conservation. Wiley, London

Morris JT (1991) Effects of nitrogen loading on wetland ecosystems with particular reference to atmospheric deposition. Annu Rev Ecol Syst 22:257-279

Nair VD, Graetz DA, Reddy KR, Olila OG (2001) Soil development in phosphate-mined created wetlands of Florida, USA. Wetlands 21 (2):232-239

Neff JC, Reynolds RL, Belnap J, Lamothe P (2008) Multi-decadal impacts of grazing on soil physical and biogeochemical properties in southeast Utah. Ecol Appl 15:87-95

Nelson FE, Anisimov OA, Shiklomanov NI (2002) Climate change and hazard zonation in the circum-arctic permafrost regions. Nat Hazards 26:203-225. doi:10.1023/A:1015612918401

Nielsen DC, Unger PW, Miller PR (2005) Efficient water use in dryland cropping systems in the Great Plains. Agron J 97(2):364-372

Nir D (1983) Man, a geomorphological agent: an introduction to anthropic geomorphology. Springer, Berlin

Norton LD (1986) Erosion-sedimentation in a closed drainage basin in northwest Indiana. Soil Sci Soc Am J 50(1):209-213

Odell RT, Walker WM, Boone LV, Oldham MG (1982) The morrow plots: a century of learning. Agricultural Experiment Station, College of Agriculture, University of Illinois Bulletin 775, Urbana-Champaign, IL

Page-Dumroese DS, Jurgensen MF, Harvey AE, Graham RT, Tonn JR (1997) Soil changes and tree seedling response associated with site preparation in northern Idaho. West J Appl For 12(3):81-88

Palm C, Sanchez P, Ahamed S, Awiti A (2007) Soils: a contemporary perspective. Annu Rev Environ Resour 32:99-129

Parent LE, Millette JA, Mehuys GR (1982) Subsidence and erosion of a Histosol. Soil Sci Soc Am J 46:404-408

Parkinson D, Coleman DC (1981) Microbial communities, activity and biomass. Agric Ecosyst Environ 34:3-33

Pellant M, Shaver P, Pyke D, Herrick JE (2005) Interpreting indicators of rangeland health, version 4. Technical reference 1734-6. US Department of the Interior, Bureau of Land Management, National Science and Technology Center, Denver, CO. BLM/WO/ST-00/001 $+1734 /$ REV05

Peterson GA, Halvorson AD, Havlin JL, Jones O, Lyon DJ, Tanaka DL (1998) Reduced tillage and increasing cropping intensity in the Great Plains conserves soil C. Soil Tillage Res 47(3):207-218

Peterson GA, Lyon DJ, Fenster CR (2012) Valuing long-term field experiments: quantifying the scientific contribution of a long-term tillage experiment. Soil Sci Soc Am J 76(3):757-765

Pickett STA (1989) Space-for-time substitution as an alternative to long-term studies. In: Likens GE (ed) Long-term studies in ecology: approaches and alternatives. Springer, New York, pp 110-135

Ping CL (2005) Cold region soils. In: Reference module in earth systems and environmental sciences, from encyclopedia of soils in the environment. Elsevier, London, pp 268-276
Ping CL (2013) Gelisols: part I. Cryogenesis and state factors of formation. Soil Horizons 54(3):1-5

Ping CL, Michaelson GJ, Kimble JM (1997) Carbon storage along a latitudinal transect in Alaska. Nutr Cycl Agroecosyst 49:235-242

Presley DR, Ransom MD, Kluitenberg GJ, Finnell PR (2004) Effects of thirty years of irrigation on the genesis and morphology of two semiarid soils in Kansas. Soil Sci Soc Am J 68:1916-1926

Preston TM, Sojda RS, Gleason RA (2013) Sediment accretion rates and sediment composition in Prairie Pothole wetlands under varying land use practices, Montana, United States. J Soil Water Conserv 68 (3):199-211

Prieto GS, Reeves DW, Shaw JN, Mitchell CC (2002) Impact of conservation tillage on soil carbon in the 'Old Rotation'. In: Proceedings of 25th annual conservation tillage conference, vol 25, pp 277-282

Pyke DA, Herrick JE, Shaver P, Pellant M (2002) Rangeland health attributes and indicators for qualitative assessment. J Range Manag 55(6):584-597

Rabenhorst MC (2001) Soils of tidal and fringing wetlands. In: Richardson JL, Vepraskas MJ (eds) Wetland soils: genesis, hydrology, landscapes, and classification. CRC Press, Boca Raton, pp 301-316

Rasmussen PE, Albrecht SL, Smiley RW (1998) Soil C and N changes under tillage and cropping systems in semi-arid Pacific Northwest agriculture. Soil Tillage Res 47(3):197-205

Ramankutty N, Foley JA (1999) Estimating historical changes in global land cover: Croplands from 1700 to 1992. Global Biogeochem Cycles 13:997-1027

Ramankutty N, Heller E, Rhemtulla J (2010) Prevailing myths about agricultural abandonment and forest regrowth in the United States. Ann Assoc Am Geogr 100(3):502-512

Reicosky DC, Saxton KE (2007) The benefits of no-tillage. In: Baker CJ, Saxton KE (eds) No-tillage seeding in conservation agriculture. Food and Agriculture Organization of the United Nations, Rome, pp 11-20

Rhoton FE, Shipitalo MJ, Lindbo DL (2002) Runoff and soil loss from midwestern and southeastern US silt loam soils as affected by tillage practice and soil organic matter content. Soil Tillage Res 66(1):1-11

Richter DdeB, Bacon AR, Megan LM, Richardson CJ, Andrews SS, West L, Wills S, Billings CA, Cambardella CA, Cavallaro N, DeMeester JE, Franzluebbers AJ, Grandy AS, Grunwald S, Gruver Hartshorn AS, Janzen H, Kramer MG, Ladha JK, Lajtha K, Liles GC, Markewitz D, Megonigal PJ, Mermut AR, Rasmussen C, Robinson DA, Smith P, Stiles CA, Tate RL, Thompson A, Tugel AJ, Van Es H, Yaalon D, Zobeck TM (2011) Human-soil relations are changing rapidly: proposals from SSSA's cross-divisional soil change working group. Soil Sci Soc Am J 75:2079-2084

Richter DdeB, Markewitz D (2001) Understanding soil change: soil sustainability over millennia, centuries, and decades. Cambridge University Press, Cambridge

Robarge WP, Johnson DW (1992) The effects of acidic deposition on forested soils. Adv Agron 47:1-83

Robertson GP, Allen VG, Boody G, Boose ER, Creamer NB, Drinkwater LE, Gosz JR, Lynch L, Havlin JL, Jackson LE, Pickett STA, Pitelka L, Randall A, Reed SA, Seastedt TR, Waide RB, Wall DH (2008) Long-term agricultural research: a research, education, and extension imperative. Bioscience 58:640 645. doi:10.1641/B580711

Robinson DA, Hockley N, Dominati E, Lebron I, Scow KM, Reynolds B, Emmett BA, Keith AM, de Jonge, LW, Schjonning P, Moldrup P, Jones SB, Tuller M (2012) Natural capital, ecosystem services, and soil change: Why soil science must embrace an ecosystems approach. Vadose Zone J 11(1): 0-0 
Rokosch AE, Bouchard V, Fennessy S, Dick R (2009) The use of soil parameters as indicators of quality in forested depressional wetlands. Wetlands 29(2):666-677

Ross MR, Castle SC, Barger NN (2012) Effects of fuels reductions on plant communities and soils in a Piñon-juniper woodland. J Arid Environ 79:84-92

Sainju UM, Lenssen A, Caesar-Tonthat T, Waddell J (2006) Tillage and crop rotation effects on dryland soil and residue carbon and nitrogen. Soil Sci Soc Am J 70:668-678

Sandor JA, Gersper PL, Hawley JW (1986) Soils at prehistoric agricultural terracing sites in New Mexico: I. Site placement, soil morphology, and classification. Soil Sci Soc Am J 50:166-173. doi:10.2136/sssaj1986.03615995005000010031x

Scavia D, Field JC, Boesch DF, Buddemeier RW, Burkett V, Cayan DR, Fogarty M, Harwell MA, Howarth RW, Reed DJ, Royer TC, Sallenger AH, Titus JG (2002) Climate change impacts on US coastal and marine ecosystems. Estuaries 25(2):149-164

Seybold CA, Herrick JE, Brejda JJ (1999) Soil resilience: a fundamental component of soil quality. Soil Sci 164(4):224-234

Seybold CA, Mersie W, Huang J, McNamee C (2002) Soil redox, pH, temperature, and water-table patterns of a freshwater tidal wetland. Wetlands 22(1):149-158

Sharratt B, Zhang M, Sparrow S (2006a) Twenty years of tillage research in subarctic Alaska II. Impact on soil strength, aggregation, roughness, and residue cover. Soil Tillage Res 91:75-81

Sharratt B, Zhang M, Sparrow S (2006b) Twenty years of conservation tillage in subarctic Alaska II. Impact on soil hydraulic properties. Soil Tillage Res 91:82-88

Sheridan RC (1979) Chemical fertilizers in southern agriculture. Agric Hist 53:308-318

Shih SF, Glaz B, Barnes RE Jr (1998) Subsidence of organic soils in the Everglades Agricultural Area during the past 19 years. Soil Crop Soc Fl Proc 57:20-29

Singer MJ, Ewing S (2000) Soil quality. In: Sumner ME (ed) Handbook of soil science. CRC Press, Boca Raton

Six JA, Elliott ET, Paustian K, Doran JW (1998) Aggregation and soil organic matter accumulation in cultivated and native grassland soils. Soil Sci Soc Am J 62(5):1367-1377

Six JA, Elliott ET, Paustian K (2000) Soil macroaggregate turnover and microaggregate formation: a mechanism for $\mathrm{C}$ sequestration under no-tillage agriculture. Soil Biol Biochem 32(14):2099-2103

Smith P, Smith JU, Powlson DS, McGil WB, Arah JRM, Chertov OG, Coleman K, Franko U, Frolking S, Jenkinson DS, Jensen LS, Kelly RH, Klein-Gunnewiek H, Komarov AS, Li C, Molina JAE, Mueller T, Parton WJ, Thornley JHM, Whitmore AP (1997) A comparison of the performance of nine soil organic matter models using datasets from seven long-term experiments. Geoderma $81: 153-225$

Soil Survey Staff (2007) Soil extent mapping tool. Natural Resources Conservation Service and Pennsylvania State University. http:// apps.cei.psu.edu/soiltool/. Accessed 16 Jan 2015

Soil Survey Staff (1999) Soil taxonomy: a basic system of soil classification for making and interpreting soil surveys, 2nd edn Natural Resources Conservation Service. U.S. Department of Agriculture Handbook 436

Sparrow SD, Lewis CL, Knight CW (2006) Soil quality response to tillage and crop residue removal under subarctic conditions. Soil Tillage Res 91:15-21

Spedding TA, Hamel C, Mehuys GR, Madramootoo CA (2004) Soil microbial dynamics in maize-growing soil under different tillage and residue management systems. Soil Biol Biochem 36(3):499512

Stephens JC, Johnson L (1951) Subsidence of organic soils in the upper Everglades region of Florida. Soil Sci Soc Fl Proc 11:191-237
Swanson FJ, Clayton JL, Megahan WF, Bush G (1989) Erosional processes and long-term site productivity. In: Perry DA, Meurisse R, Thomas B, Miller R, Boyle J, Means J, Perry CR, Powers RF (eds) Maintaining the long-term productivity of pacific northwest forest ecosystems. Timber Press, Portland, pp 67-81

Tarnocai C (2009) Arctic permafrost soils. In: Margesin R (ed) Permafrost soils. Soil biology series, vol 16. Springer, Berlin, pp 3-16

Tate KW, Dudley DW, McDougald NK, George MR (2004) Effect of canopy and grazing on soil bulk density. Rangel Ecol Manag 57 (4):411-417

Torsvik V, Øvreås L (2002) Microbial diversity and function in soil: from genes to ecosystems. Curr Opin Microbiol 5(3):240-245

Trimble SW (1974) Man-induced soil erosion on the southern Piedmont, 1700-1970. Soil Conservation Society of America, Madison

Trimble SW, Mendel AC (1995) The cow as a geomorphic agent-a critical review. Geomorphology 13(1):233-253

Tugel AJ, Herrick JE, Brown JR, Mausbach MJ, Puckett W, Hipple K (2005) Soil change, soil survey, and natural resources decision making. Soil Sci Soc Am J 69:738-747. doi:10.2136/sssaj2004. 0163

Tugel AJ, Wills SA, Herrick JE (2008) Soil change guide. In: Procedures for soil survey and resource inventory. Version 1.1. National Soil Survey Center, Lincoln, NE

Turner RE (2011) Beneath the salt marsh canopy: loss of soil strength with increasing nutrient loads. Estuar Coasts 34(5):1084-1093

USDA-National Agriculture Statistics Service (NASS) (2007) Census of agriculture: volume 3 special studies part 1. http://www.nass. usda.gov/research/2007mapgallery/album/Farms/Land_in_Farms and_Land_Use/slides/Acres\%20of\%20Irrigated\%20Land.html. Accessed online 15 Jan 2015

USGS (2014a) Mineral resources online spatial data.US Geological Survey. http://mrdata.usgs.gov/mineral-resources/phosphate.html. Last modified 3 September 2014. Accessed 26 Nov 2014

USGS (2014b) Mineral commodity summaries: phosphate rock. US Geological Survey, Reston, pp 118-119

van Auken OW (2000) Shrub invasions of North American semiarid grasslands. Annu Rev Ecol Syst 31:197-215

Vitousek PM, Bolin B, Cook RB (1983) The effects of deforestation on air, soil, and water. In: Bolin B, Cook RB (eds) Major Biogeochem Cycles Interact. John Wiley \& Sons, Chichester, pp 223-245

Walker DA, Everett KR (1987) Road dust and its environmental impact on Alaskan taiga and tundra. Artic Alpine Res 19(4):479-489

Wallace PM, Best GR (1983) Enhancing ecological succession: 6. Succession of endomycorrhizal fungi on phosphate strip mined lands. In: Proceedings of the 1983 symposium on surface mining, hydrology, sedimentology, and reclamation. University of Kentucky, Lexington

Wander MM, Hedrick DS, Kaufman D, Traina SJ, Stinner BR, Kehrmeyer SR, White DC (1995) The functional significance of the microbial biomass in organic and conventionally managed soils. Plant Soil 170:87-97

Wardle DA, Yeates GW, Nicholson KS, Bonner KI, Watson RN (1999) Response of soil microbial biomass dynamics, activity and plant litter decomposition to agricultural intensification over a seven year period. Soil Biol Biochem 31:1707-1720

Webb BB, Tucker BB, Westerman RL (1980) The Magruder Plots: taming the prairies through research. Agricultural Experimental Station, Oklahoma State University, Stillwater

Weir WW (1950) Subsidence of peat lands of the Sacramento-San Joaquin delta, California. Hilgardia 20:37-56

West TO, Post WM (2002) Soil organic carbon sequestration rates by tillage and crop rotation: a global data analysis. Soil Sci Soc Am J 66:1930-1946 
Whitlock C, Shafer SL, Marlon J (2003) The role of climate and vegetation change in shaping past and future fire regimes in the northwestern US and the implications for ecosystem management. For Ecol Manag 178(1):5-21

Williams MA (2001) Influence of water on the carbon and nitrogen dynamics of annually-burned tallgrass prairie. Ph.D. dissertation, Kansas State University, Manhattan

Williams JR, Sharpley AN (eds) (1989) EPIC-erosion-productivity impact calculator: 1. Model documentation, USDA Tech. Bulletin No. (1768) USDA, Washington, DC

Williams JR, Izaurralde RC, Steglich EM (2008) Agricultural Policy/Environmental eXtender Model: Theoretical Documentation Version 0604. BREC Report No. 2008-17. Texas A\&M University. Blackland Research and Extension Center, Temple, TX

Williams CO, Lowrance R, Bosch DD, Williams JR, Benham E, Dieppa A, Hubbard R, Mas E, Potter T, Sotomayor D, Steglich EM, Strickland T, Williams RG (2013) Hydrology and water quality of a field and riparian buffer adjacent to a mangrove wetland in Jobos Bay Watershed, Puerto Rico. Ecol Eng 56:60-68. doi:10.1016/j. ecoleng.2012.09.005
Wilson M, Hanlon EA (2012) Florida reclaimed phosphate mine soils: characteristics, potential uses, and management considerations. University of Florida Extension Publication \#SL370

Wood CW, Edwards JH (1992) Agroecosystem management effects on soil carbon and nitrogen. Agric Ecosyst Environ 39:123-138

Wright JO (1907) Swamp and overflowed lands of the United States: ownership and reclamation, vol 76. United States Department of Agriculture, Government Printing Offices, USA

Yaalon DH (2007) Human-induced ecosystem and landscape processes always involve soil change. Bioscience 57:918-919

Yaalon DH, Yaron B (1966) Framework for man-made soil changes: an outline of metapedogenesis. Soil Sci 4(102):272-277

Zak DR, Grigal DF, Gleeson S, Tillman D (1990) Carbon and nitrogen cycling during old-field succession: constraints on plant and microbial biomass. Biogeochemistry 11:111-129

Zedler JB, Kercher S (2005) Wetland resources: status, trends, ecosystem services, and restorability. Annu Rev Environ Resour 30:39-74

Zhang M, Sparrow SE, Van Veldhuizen B, Masiak DT (2012) Soil quality under different land uses in a subarctic environment in Alaska. J Land Use Sci 7(1):109-121. 